\title{
Establishment of a Cell-Free System of Neuronal Apoptosis: Comparison of Premitochondrial, Mitochondrial, and Postmitochondrial Phases
}

\author{
H. Michael Ellerby, ${ }^{1}$ Seamus J. Martin, ${ }^{2}$ Lisa M. Ellerby, ${ }^{1}$ Shahrouz S. Naiem, ${ }^{1,6}$ Shahrooz Rabizadeh, ${ }^{1,7}$ \\ Guy S. Salvesen, ${ }^{1}$ Carlos A. Casiano, ${ }^{3}$ Neil R. Cashman, ${ }^{4}$ Douglas R. Green, ${ }^{5}$ and Dale E. Bredesen ${ }^{1,7}$ \\ 1 The Burnham Institute, La Jolla Cancer Research Center, La Jolla, California 92037, ${ }^{2}$ Molecular Cell Biology Laboratory, \\ Maynooth University College, County Kildare, Ireland, ${ }^{3}$ Department of Molecular and Experimental Medicine, The Scripps \\ Research Institute, La Jolla, California 92037, 4 Montreal Neurological Institute, McGill University, Montreal, Quebec, \\ Canada H3A 2B4, 5 La Jolla Institute for Allergy and Immunology, San Diego, California 92121, ${ }^{\circ}$ Program in Molecular \\ Pathology, University of California, San Diego, California 92093, and 7Interdepartmental Program in Neuroscience, \\ University of California, Los Angeles, California 90024
}

\begin{abstract}
Apoptosis is a fundamental process required for normal development of the nervous system and is triggered during neurodegenerative disease. To dissect the molecular events leading to neuronal cell death, we have developed a cell-free model of neuronal apoptosis. The model faithfully reproduces key elements of apoptosis, including chromatin condensation, DNA fragmentation, caspase activation/processing, and selective substrate cleavage. We report that cell-free apoptosis is activated in premitochondrial, mitochondrial, and postmitochondrial phases by tamoxifen, mastoparan, and cytochrome $c$,
\end{abstract}

respectively, allowing a functional ordering of these proapoptotic modulators. Furthermore, this is the first report of mitochondrial-mediated activation of cell-free apoptosis in a cell extract. Although Bcl-2 blocks activation at the premitochondrial and mitochondrial levels, it does not affect the postmitochondrial level. The cell-free system described here provides a valuable tool to elucidate the molecular events leading to neuronal cell death.

Key words: caspase; protease; apoptosis; cell-free; mitochondria; mastoparan; neuronal
Accumulating evidence suggests that neuronal apoptosis plays a role not only in nervous system development but also in neurological disease states (Bredesen, 1994). Evidence has been presented for apoptotic neuronal cell death in stroke (Linnik et al., 1993), Parkinson's disease (Mochizuki et al., 1996), Alzheimer's disease (Cotman and Anderson, 1995), amyotrophic lateral sclerosis (ALS) (Yoshiyama et al., 1994), human immunodeficiency virus encephalopathy (Gelbard et al., 1995), cerebral trauma (Rink et al., 1995), Huntington's disease (Dragunow et al., 1995), and other diseases (Bredesen, 1994).

In addition to evidence of neuronal apoptosis in disease states, some of the mutations associated with neurodegenerative diseases have been shown to have proapoptotic effects in cell culture models. For example, mutations of sod1, which encodes copper/ zinc superoxide dismutase (CuZnSOD), are associated with familial amyotrophic lateral sclerosis (Rosen et al., 1993), and these mutations have been shown to convert CuZnSOD from manifesting an antiapoptotic effect on cultured neural cells to manifesting a proapoptotic effect (Rabizadeh et al., 1995). Similarly, Alzheimer's disease-associated mutations at amyloid precursor protein residue 717 (APP717 mutations) have been shown to be proapoptotic (Yamatsuji et al., 1996a,b).

Received March 17, 1997; revised May 9, 1997; accepted May 23, 1997.

This work was supported by National Institutes of Health Grants AG12282 and CA69381 (to D.E.B.) and CA69381 (to D.R.G.). H.M.E. is a National Institutes of Health Senior Research Fellow (NS10050-02). S.J.M. is a Wellcome Trust Senior Fellow (047580).

Correspondence should be addressed to Dr. Dale Bredesen, Program on Aging, The Burnham Institute, La Jolla Cancer Research Center, 10901 North Torrey Pines Road, La Jolla, CA 92037.

Copyright (C) 1997 Society for Neuroscience $\quad 0270-6474 / 97 / 176165-14 \$ 05.00 / 0$
Cell-free systems (CFSs) have proven to be invaluable for the study of a number of cellular events such as mitosis (Lee and Kirschner, 1996), protein translocation, and post-translational modification (Rothman, 1990) as well as apoptosis of non-neural cells (Lazebnik et al., 1993; Newmeyer et al., 1994; Martin et al., 1995a; Liu et al., 1996), among others. To dissect the events of neuronal apoptosis, we have developed a CFS that recapitulates the events of neuronal apoptosis, including nuclear morphological changes, internucleosomal fragmentation of DNA, caspase activation [cysteine proteases cleaving after aspartic acid (Alnemri et al., 1996)], and the proteolytic cleavage of key substrates. The system is applied to primary cultures of cerebellar neurons and several neural cell lines.

Next, we report on the application of the system to the ordering of the events of neuronal apoptosis. (1) Premitochondrial level. Tamoxifen, an antiestrogenic and antineoplastic agent (Pollak, 1996), activates apoptosis in whole cells from which an apoptotically active extract then may be prepared. However, it does not activate a normal cell extract, whether or not mitochondria are added to the extract. (2) Mitochondrial level. Mastoparan, a peptide toxin from wasp (Vespula lewisii) venom (Hirai et al., 1979), induces apoptosis in whole cells from which an apoptotically active extract then may be prepared. Furthermore, it activates a normal cell extract, provided that mitochondria are added to the extract. (3) Postmitochondrial level. Cytochrome $c$ and dATP, added together, do not activate apoptosis in whole cells. However, they do activate a normal cell extract, whether or not mitochondria are added to the extract. Furthermore, they activate a normal extract made from $b c l$-2-overexpressing cells, whether or not mitochondria from $b c l$-2-overexpressing cells are present. 
Taken together, our findings argue for a general ordering of neuronal apoptotic events as premitochondrial (or extramitochondrial), mitochondrial, and postmitochondrial.

\section{MATERIALS AND METHODS}

Cell culture. Primary cultures of rat cerebellar neurons were prepared by a procedure that combines elements of the method of Schousboe et al. (1989) with that of Cole and de Vellis (1989). Sprague Dawley rat pups between 5 and $7 \mathrm{~d}$ were alcohol-sterilized and decapitated. Gross dissection of each brain, microdissection of the cerebellum, and plating were performed in DMEM supplemented with $4.5 \mathrm{~g} / 1$ glucose, L-glutamine, $10 \%$ heat-inactivated fetal bovine serum (FBS), and 1\% penicillin/ streptomycin (P/S). The Nitex bag method of Lu et al. (1980) was used to dissociate the cerebellar tissue. Then the cells were plated at a density of $10 \% / \mathrm{ml}$ on $\sim 2000 \mathrm{~mm}^{2}$ tissue culture plates, which were coated with poly-L-lysine at $20 \mu \mathrm{g} / \mathrm{ml}$. The cells were incubated at $37^{\circ} \mathrm{C}$, with a $5 \%$ $\mathrm{CO}_{2} / 95 \%$ air mixture. After a $48 \mathrm{hr}$ incubation, the cells were treated with cytosine $\beta$-D-arabinoside at $40 \mu \mathrm{M}$.

CSM 14.1 cells (Zhong et al., 1993a) are neural by neurofilament staining (NF-H) at the restrictive temperature of $39^{\circ} \mathrm{C}$ and by expression of tyrosine hydroxylase mRNA, suggesting that they are a dopaminergic precursor. CSM-25, a subclone of CSM 14.1, was selected for its high propensity to undergo apoptosis after serum withdrawal. CSM-25 cells were grown at $34^{\circ} \mathrm{C}$, with a $5 \% \mathrm{CO}_{2} / 95 \%$ air mixture, in the same type of medium as that used for the cerebellar neurons.

The NSC-34 and NSC-19 cell lines appear to mimic selected aspects of motor neuron development in an immortalized clonal system (Cashman et al., 1992). These cell lines display a multipolar neuron-like phenotype, express choline acetyltransferase, and induce twitching in cocultured mouse myotubes. They were grown at $37^{\circ} \mathrm{C}$ with a $5 \% \mathrm{CO}_{2} / 95 \%$ air mixture in DMEM (Life Technologies, Gaithersburg, MD) supplemented with $4.5 \mathrm{gm} / 1$ glucose, L-glutamine, $10 \%$ heat-inactivated FBS (Summit Biotechnology, Ft. Collins, CO), and 1\% P/S.

The human teratocarcinoma cell line NT2/D1 can be manipulated after treatment of retinoic acid to yield $>99 \%$ pure cultures of terminally differentiated NT2-N neurons (Pleasure and Lee, 1993). NT2/D1 cells were grown at $37^{\circ} \mathrm{C}$ with a $5 \% \mathrm{CO}_{2} / 95 \%$ air mixture in Opti-MEM (Life Technologies) supplemented with $10 \%$ heat-inactivated FBS and $1 \% \mathrm{P} / \mathrm{S}$.

The R2 cell line is a conditionally immortalized cerebellar neural line (Rabizadeh et al., 1993). The R2 cells were grown at $34^{\circ} \mathrm{C}$ in the same medium as that used for the cerebellar neurons. Jurkat and HeLa cells were grown at $37^{\circ} \mathrm{C}$ with a $5 \% \mathrm{CO}_{2} / 95 \%$ air mixture in RPMI 1640 medium supplemented with L-glutamine, $10 \%$ heat-inactivated FBS, and $1 \% \mathrm{P} / \mathrm{S}$.

Activation of cellular apoptosis. Staurosporine, tamoxifen citrate, 4-hydroxy-tamoxifen, and tamoxifen were purchased from Sigma Chemical (St. Louis, MO). Cells were induced to undergo apoptosis by exposure to $10 \mu \mathrm{M}$ staurosporine or exposure to $100 \mu \mathrm{M}$ tamoxifen citrate (or 4-hydroxytamoxifen or tamoxifen) for times ranging from 1 to $24 \mathrm{hr}$.

Preparation of cell lysates. Cells incubated with either $100 \mu \mathrm{M}$ tamoxifen or $10 \mu \mathrm{M}$ staurosporine were collected at the indicated time points. The plates were placed on ice, and all subsequent steps were performed either on ice or at $4^{\circ} \mathrm{C}$. The $20 \mathrm{ml}$ of media in each plate containing any detached cells was saved in a $50 \mathrm{ml}$ conical centrifuge tube. The adherent cells received $20 \mathrm{ml}$ of PBS and then were lifted gently off the plate with a cell scraper and pooled with the detached cells. A final $10 \mathrm{ml}$ was used to wash off the plate completely. The combined $50 \mathrm{ml}$ was placed on ice and treated with the protease inhibitor cocktail Complete (Boehringer Mannheim, Mannheim, Germany). Cells were pelleted at $400 \times g$ for 5 min at $4^{\circ} \mathrm{C}$, washed again in $15 \mathrm{ml}$ of PBS treated with Complete, and repelleted in a $15 \mathrm{ml}$ conical centrif uge tube. The cells were resuspended in lysis buffer (containing $62.5 \mathrm{~mm}$ Tris-HCl, pH 6.8, 1\% SDS, $10 \%$ glycerol, $1 \%$ mercaptoethanol, and Complete), boiled for $5 \mathrm{~min}$, passed through a 27 -gauge needle to shear the DNA, and stored at $-84^{\circ} \mathrm{C}$ for later Western blot analysis.

Preparation of cytoplasmic extracts. The first type of cytoplasmic extract used in this work, known as " $16,000 \times g$ extract," does not contain whole cells, nuclei, and mitochondria. The required plates were removed from the incubator and immediately were placed on ice. The $20 \mathrm{ml}$ of media in a plate was removed and discarded, and another $10 \mathrm{ml}$ of ice-cold PBS, pH 7.2, was added to the plate. Then the cells were lifted gently, but quickly, off the plate with a cell scraper, placed on ice in a 50 $\mathrm{ml}$ centrifuge tube, and centrifuged $\left(4^{\circ} \mathrm{C}\right)$ at $200 \times g$. The resulting cell pellet was washed in $50 \mathrm{ml}$ of ice-cold PBS. The cells were resuspended in a $15 \mathrm{ml}$ conical centrifuge tube with $10 \mathrm{ml}$ of hypotonic extraction buffer [HEB; containing (in mM): 50 PIPES, pH 7.4, $50 \mathrm{KCl}, 5$ EGTA, $2 \mathrm{MgCl}_{2}, 1$ dithiothreitol (DTT), and 0.1 phenylmethylsulfonyl fluoride (PMSF)]. The cells were centrifuged at $1000 \times g\left(4^{\circ} \mathrm{C}\right)$ to form a tight pellet, and the volume of the cell pellet was approximated. The supernatant was aspirated, and HEB was added to a volume between 0.5 and $1 \times$ the pellet volume. The cells were transferred to a $2 \mathrm{ml}$ Dounce homogenizer and allowed to swell for 20-30 min on ice. Cells were lysed with 20-100 gentle strokes of a B-type pestle. The desired extent of lysis $(>90 \%)$ was monitored under the microscope by trypan blue staining. The volume of HEB added, the time of swelling, and the number of pestle strokes all varied according to the cell type. Then the cell lysate was transferred to an Eppendorf tube and centrifuged for $30 \mathrm{~min}$ at $16,000 \times g\left(4^{\circ} \mathrm{C}\right)$. The clarified supernatant was removed carefully and either was used immediately or stored in aliquots at $-84^{\circ} \mathrm{C}$.

The second type of cytoplasmic extract used in this work, known as "3000 × $g$ extract," contains mitochondria along with pieces of plasma membrane et cetera, but not whole cells or nuclei. The method here is the same as that for $16,000 \times g$ extracts, with the following differences. The lysis buffer is the CFS buffer used by Susin et al. (1996) [containing (in mM): 220 mannitol, 68 sucrose, $2 \mathrm{NaCl}, 2.5 \mathrm{KH}_{2} \mathrm{PO}_{4}, 0.5$ EGTA, 2 $\mathrm{MgCl}_{2}, 5$ pyruvate, 0.1 PMSF, 2 ATP, 10 phosphocreatine, 1 DTT, and $10 \mathrm{HEPES}-\mathrm{NaOH}, \mathrm{pH} 7.4$, with $50 \mu \mathrm{g} / \mathrm{ml}$ creatine phosphokinase], supplemented with the protease inhibitors leupeptin $(1 \mu \mathrm{g} / \mathrm{ml})$, pepstatin A $(1 \mu \mathrm{g} / \mathrm{ml})$, antipain $(50 \mu \mathrm{g} / \mathrm{ml})$, and chymostatin $(10 \mu \mathrm{g} / \mathrm{ml})$. After lysis of the cells in a Potter-Elvehjem homogenizer, the homogenate was centrifuged for $5 \mathrm{~min}$ at $1000 \times g\left(4^{\circ} \mathrm{C}\right)$ to remove whole cells and nuclei. Then the supernatant was centrifuged for $5 \mathrm{~min}$ at $3000 \times g\left(4^{\circ} \mathrm{C}\right)$. The protease inhibitors were purchased from Boehringer Mannheim.

Protein determination. The Pierce Coomassie Plus protein assay with BSA standard was used to assay protein concentration in cell extracts with a Shimadzu UV-2101 PC UV-Vis Scanning Spectrophotometer.

Preparation of nuclei. Rat liver nuclei were prepared as described (Newmeyer et al., 1994). CSM and HeLa nuclei were prepared as described (Martin et al., 1995a).

Preparation of mitochondria. Rat and mouse liver mitochondria were prepared as described by Hovius et al. (1990), with modifications. Briefly, adult Sprague Dawley rats $(\sim 250 \mathrm{gm})$ or adult BALB/c mice $(\sim 50 \mathrm{gm})$ were fasted for $6 \mathrm{hr}$ and then killed by $\mathrm{CO}_{2}$ inhalation (or cervical dislocation). The livers were removed quickly and submerged in ice-cold mitochondria isolation buffer [MIB; containing (in $\mathrm{mM}$ ): 250 mannitol (or sometimes 210 mannitol and 70 sucrose), 0.5 EGTA, and 5 HEPES with $0.1-0.05 \%(\mathrm{w} / \mathrm{v}) \mathrm{BSA}, \mathrm{pH} 7.2$ ], supplemented with the protease inhibitors of leupeptin $(1 \mu \mathrm{g} / \mathrm{ml})$, pepstatin A $(1 \mu \mathrm{g} / \mathrm{ml})$, antipain $(50$ $\mu \mathrm{g} / \mathrm{ml})$, and chymostatin $(10 \mu \mathrm{g} / \mathrm{ml})$. All subsequent steps were performed on ice or at $4^{\circ} \mathrm{C}$. The livers were washed in MIB and then chopped into $1-2 \mathrm{~mm}^{2}$ cubes. These cubes were rinsed and transferred to a $15 \mathrm{ml}$ Potter-Elvehjem homogenizer. Using a tight-fitting Tefloncoated pestle, we homogenized the tissue by $6-10$ up and down strokes at $\sim 600 \mathrm{rpm}$. Large cell debris and nuclei were pelleted by centrif uging twice for $5 \mathrm{~min}$ at $600 \times \mathrm{g}$. Mitochondria were pelleted by centrifuging the supernatant for $10 \mathrm{~min}$ at $10,300 \times \mathrm{g}$. After the pellet was suspended in $5 \mathrm{ml}$ of MIB, the suspension was loaded on a continuous Percoll gradient. Then the suspension/gradient was centrifuged at $40,000 \times g$ for $40 \mathrm{~min}$. The mitochondria were removed from the brown band at $\sim 1.10$ $\mathrm{g} / \mathrm{ml}$ with a Pasteur pipette. The mitochondrial pellets were washed with MIB by centrifuging for $10 \mathrm{~min}$ at $6300 \times g$. Then the mitochondria were suspended gently in mitochondria storage buffer [MSB; containing (in $\mathrm{mM}$ ): 400 mannitol, $10 \mathrm{KH}_{2} \mathrm{PO}_{4}$, and 50 Tris- $\mathrm{HCl}$, $\mathrm{pH} \mathrm{7.2,} \mathrm{with} 5 \mathrm{mg} / \mathrm{ml}$ $\mathrm{BSA}]$ and stored on ice for up to $4 \mathrm{hr}$. Cultured cell mitochondria were prepared as described previously (Moreadith and Fiskum, 1984).

Activation of cell-free apoptosis. For reactions with primed and apoptotic extracts, two systems were reconstituted. First were reactions of primed (or apoptotic) extract on nuclear substrates: $20 \mu \mathrm{l}$ of normal, primed, or apoptotic $16,000 \times g$ extract $(15-25 \mathrm{mg} / \mathrm{ml}$ protein), $1 \mu \mathrm{l}$ of nuclei $\left(2 \times 10^{5}\right)$, and $4 \mu$ l of HEB buffer or synthetic inhibitor peptides diluted in this buffer to a total volume of $25 \mu \mathrm{l}$. Second were reactions of primed (or apoptotic) extract on cytosolic substrates: $20 \mu \mathrm{l}$ of normal cytoplasmic extract (15-25 mg/ml protein), $5 \mu$ l of primed or apoptotic cytoplasmic extract (15-25 mg/ml protein), and $4 \mu$ l of HEB buffer or synthetic peptides diluted in this buffer.

For reactions activated by cytochrome $c$ and dATP, a system was reconstituted according to the following formula: $10 \mu \mathrm{l}$ of $16,000 \times g$ normal extract, $0.1 \mu \mathrm{l}$ cytochrome $c(1-10 \mu \mathrm{M}$ final), and $0.1 \mu \mathrm{l}$ of dATP 
(10 mM final), 1-2 $\mu$ l of peptide (or other) inhibitors or HEB buffer, and $0.5-1 \mu \mathrm{l}$ of nuclei $\left(2 \times 10^{5}\right)$ or HEB buffer.

For cell-free reactions activated by mastoparan or atractyloside, two systems were reconstituted. First were reactions involving $3000 \times g$ extracts: $20 \mu \mathrm{l}$ normal extract and $2 \mu \mathrm{l}$ of atractyloside $(5 \mathrm{~mm}$ final concentration) or mastoparan (10-50 $\mu \mathrm{M}$ final concentration) or CFS buffer. Second were reactions involving $16,000 \times g$ extracts: in these reactions the ionic strength/osmolarity of the extract was altered to account for the $50 \%$ of the extract composed of hypotonic buffer. Mitochondria were washed once and resuspended in CFS to $\geq 40 \mathrm{mg} / \mathrm{ml}$. Then the mitochondria were added to extract with mastoparan or atractyloside according to the following formula: $20 \mu \mathrm{l}$ normal extract, $2 \mu \mathrm{l}$ of mitochondria, and $2 \mu \mathrm{l}$ of atractyloside ( $5 \mathrm{~mm}$ final concentration) or mastoparan (10-50 $\mu \mathrm{M}$ final concentration) or CFS buffer.

$N$-benzyloxycarbonyl-Val-Ala-Asp.fluoromethylketone (zVAD.fmk) was purchased from Enzyme Systems (Dublin, CA). Ac-YVAD aldehyde and Ac-DEVD-aldehyde were purchased from Bachem Bioscience (Torrance, CA). Bovine and horse heart cytochrome $c$, yeast (ISO-1) cytochrome $c$, and partially acetylated cytochrome $c$ were purchased from Sigma or Fluka BioChemika (Ronkonkoma, NY). dATP was purchased from Promega (Madison, WI). Sodium and potassium atractyloside and mastoparan were purchased from Sigma. Control peptide (DLSLARLATARLAI) was purchased from Coast Scientific (San Diego, CA).

Release of cytochrome c from mitochondria. In this experiment $2 \mu \mathrm{l}$ of mastoparan (10-100 $\mu \mathrm{M}$ final concentration) and $2 \mu \mathrm{l}$ of mitochondria $(500 \mathrm{ng} / \mathrm{ml}$ final concentration) were added to $20 \mu \mathrm{l}$ of CFS buffer. Reactions were run as above (see Activation of Cell-Free Apoptosis), except that at the end of the incubation period reaction tubes were spun at $12,000 \times g$ for $3 \mathrm{~min}$ to pellet the mitochondria. Then the pellet and the supernatant were subjected to Western blot analysis with cytochrome $c$ antibody.

For cell-free reactions activated by a mastoparan-treated mitochondrial fraction, a system was reconstituted according to the following formula: in this experiment, reactions just like those above were run, but then the supernatants were mixed with normal extract in the formulation of $20 \mu \mathrm{l}$ normal extract and $5 \mu \mathrm{l}$ of supernatant. The supernatant was concentrated from 50 to $5 \mu \mathrm{l}$, using a 3000 Da cutoff protein Microconcentrator (Amicon, Beverly, MA).

Quantification of apoptosis. Cells undergoing morphological changes associated with apoptotic cell death were monitored as previously described (McGahon et al., 1995). Briefly, at the given time points, cell culture medium was aspirated from adherent cells, and the cells were gently washed once with room temperature PBS. Then 1-2 $\mathrm{ml}$ of a 20 -fold dilution of the dye mixture (composed of $100 \mu \mathrm{g} / \mathrm{ml}$ acridine orange and $100 \mu \mathrm{g} / \mathrm{ml}$ ethidium bromide) in PBS with formalin was pipetted gently on the cells and viewed on an inverted fluorescence microscope. Cells were scored as apoptotic if their nuclei exhibited margination and condensation of the chromatin and/or nuclear fragmentation similar to that observed in normal apoptotic cells (Martin et al., 1995a). A minimum of 300 cells were scored for each time point.

The procedure for the quantification of cell-free apoptosis was essentially the same as that for cellular apoptosis, except that at the time points indicated in the text a $3.5 \mu \mathrm{l}$ aliquot of cell-free reaction mixture containing nuclei was removed, stained with $1.5 \mu \mathrm{l}$ of the dye mixture described above, and placed on a glass slide. Nuclei were scored as apoptotic if they exhibited morphological changes similar to those observed in the nuclei of apoptotic cells. On each slide a minimum of 300 nuclei were scored for quantification of apoptosis.

Protein electrophoresis and Western blots. Electrophoresis of proteins was performed with either 8 or $12 \%$ SDS-polyacrylamide gels. Equal amounts of total protein were loaded per lane, and proteins were separated at $4^{\circ} \mathrm{C}$ under reducing conditions at $70 \mathrm{~V}$. Western blot transfer of separated proteins was performed at $4^{\circ} \mathrm{C}$, using polyvinylidene fluoride membranes at $200 \mathrm{~mA}$ for $2 \mathrm{hr}$. Blots were blocked for $1 \mathrm{hr}$ in TBST (10 mM Tris- $\mathrm{HCl}, \mathrm{pH} 7.5,150 \mathrm{~mm} \mathrm{NaCl}$, and $0.1 \%$ Tween) containing 5\% nonfat dried milk. Next, the membranes were probed with an appropriate dilution (1:500 to 1:2000) of primary antibody in TBST containing 5\% nonfat dried milk for $1 \mathrm{hr}$.

Anti- $\alpha$-fodrin mouse monoclonal antibody was purchased from Chemicon (Temecula, CA). Anti-nPKC- $\delta$ rabbit polyclonal antibody was purchased from Santa Cruz Biotechnology (Santa Cruz, CA). Anti-poly (ADP-ribose) polymerase (PARP) rabbit polyclonal antibody was purchased from Biomol Research Laboratories (Plymouth Meeting, PA); anti-CPP32 mouse monoclonal antibody was purchased from Transduction Laboratories (Lexington, KY). Anti-CPP32 rabbit polyclonal anti- body was purchased from Upstate Biotechnology (Lake Placid, NY). Anti-CPP32 goat polyclonal antibody was purchased from Santa Cruz Biotechnology. Anti-lamin B mouse monoclonal mouse antibody was purchased from Oncogene Research Products (Calbiochem, La Jolla, CA). Anti-cytochrome $c$ mouse monoclonal antibody was a generous gift of Dr. Ronald Jemmerson (University of Minnesota Medical School, Minneapolis, MN). Human sera containing highly specific high-titer autoantibodies to PARP, DNA topoisomerase I, U1-70 kDa, NuMa, Lamin B, Jo-1, rRNP, and PCNA were from the collection of W. M. Keck Autoimmune Disease Center Laboratory (The Scripps Research Institute, La Jolla, CA) serum bank (Casiano et al., 1996).

Then the blots were washed for $1 \mathrm{hr}$ with frequent changes of TBST, followed by incubation in a peroxidase-coupled secondary antibody for 1 hr in TBST containing 5\% nonfat dried milk. The blots were washed for $1 \mathrm{hr}$ with frequent changes of TBST. Enhanced chemiluminescence detection of the proteins was performed with Hyperfilm ECL (Amersham, Arlington Heights, IL) and Pierce SuperSignal Substrate Western Blotting reagents (Rockford, IL).

Internucleosomal DNA fragmentation. After incubation in the cytoplasmic extracts for various time periods, nuclei were lysed in TE buffer (50 mM Tris- $\mathrm{HCl}, \mathrm{pH} 8.0$, and $10 \mathrm{~mm}$ EDTA) containing $0.5 \%$ sodium lauryl sarkosyl and $0.5 \mathrm{mg} / \mathrm{ml}$ proteinase K. Digestion was continued for $1-3 \mathrm{hr}$ at $50^{\circ} \mathrm{C}$, followed by the addition of Rnase A to $1.0 \mathrm{mg} / \mathrm{ml}$ and further incubation for $1 \mathrm{hr}$. Then running dye was added, and the preparations were electrophoresed in 1.5-2\% agarose gels in TAE buffer $(40 \mathrm{~mm}$ Tris-acetate and $1 \mathrm{~mm}$ EDTA) or TBE buffer ( $40 \mathrm{~mm}$ Tris-borate and 1 mM EDTA) at $4 \mathrm{~V} / \mathrm{cm}$ of gel $(30-35 \mathrm{~V})$. DNA was visualized by ethidium bromide staining.

Measurement of caspase activation and activity. For the caspase activation assay, the following CFS was reconstituted. First, a $100 \mu \mathrm{l}$ aliquot (at least) of $16,000 \times g$ extract was clarified a second time for $20-30 \mathrm{~min}$ at $4^{\circ} \mathrm{C}$, in that the spectrophotometer gave irreproducible results unless the extract was clarified fully. Then, $1 \mu$ l of DEVD-pNA or YVAD-pNA substrate $(100 \mu \mathrm{M}$ final concentration) was added to $50 \mu \mathrm{l}$ of the $16,000 \times$ $g$ normal extract (15-25 $\mathrm{mg} / \mathrm{ml}$ protein) and allowed to come to thermal equilibrium for $2-3 \mathrm{~min}$ at either 30 or $37^{\circ} \mathrm{C}$ in a well of a Corning 96-well plate placed in a Molecular Devices MAXline Microplate Spectrophotometer (Menlo Park, CA). Next, $1 \mu \mathrm{l}$ of cytochrome $c(1-10 \mu \mathrm{M}$ final concentration) and $1 \mu \mathrm{l}$ of dATP (1 mM final concentration) were added, along with $1 \mu \mathrm{l}$ of inhibitor or buffer. Hydrolysis of the substrate was followed spectrophotometrically at $405 \mathrm{~nm}$ for $30-60 \mathrm{~min}$ at either 30 or $37^{\circ} \mathrm{C}$.

For the study of caspase activity a CFS was reconstituted according to the following formula: $10 \mu \mathrm{l}$ of $16,000 \times g$ normal extract, $0.1 \mu \mathrm{l}$ cytochrome $c(1-10 \mu \mathrm{M}$ final), and $0.1 \mu \mathrm{l}$ of dATP (10 mM final), 1-2 $\mu \mathrm{l}$ of peptide (or other) inhibitors or HEB buffer, and $0.5-1 \mu \mathrm{l}$ of nuclei $\left(2 \times 10^{5}\right)$ or HEB buffer. After the incubation was complete, a 1-8 $\mu$ l aliquot of extract from a cell-free reaction was added to $100 \mu \mathrm{l}$ of assay buffer $(10 \%$ sucrose, $50 \mathrm{~mm}$ HEPES, $100 \mathrm{~mm} \mathrm{NaCl}$, and $0.1 \%$ CHAPS, pH 7.4.) containing $100 \mu \mathrm{M}$ DEVD-pNA $N$-acetyl-Asp-Glu-Val-AsppNA. Hydrolysis of the substrate was followed spectrophotometrically at $405 \mathrm{~nm}$ for $30-60 \mathrm{~min}$ at either 30 or $37^{\circ} \mathrm{C}$.

The substrates DEVD-pNA [sequence; $N$-acetyl-Asp-Glu-Val-AsppNA ( $p$-nitroanilide); (Lazebnik et al., 1994)] and YVAD-pNA [sequence; $N$-acetyl-Tyr-Val-Ala-Asp-pNA; (Reiter, 1994)] were purchased from Biomol Research Laboratories.

\section{RESULTS}

\section{Activation of neural apoptosis with staurosporine}

Many of the stimuli that induce apoptotic cell death in neural cell lines induce it over several days, a condition that results in mixed populations of apoptotic and viable cells. Furthermore, the dying cells are in various stages of apoptosis. For example, $100 \mu \mathrm{M}$ $\mathrm{H}_{2} \mathrm{O}_{2}, 10$ min of UV exposure, withdrawal of trophic factors, and serum withdrawal all induce slow neural cell death $(>30 \mathrm{hr}$ for $50 \%$ cell death) (Bredesen, 1994), with significant numbers of cells passing through all phases of death from early apoptosis to secondary necrosis. Such asynchronous apoptosis makes it unfeasible to make extract from cells at, or near, the same stage of cell death. Synchronous cell extracts are required to study effectively the temporal ordering of events in apoptosis (e.g., a protease cascade) or to make a so-called primed extract, which is made 

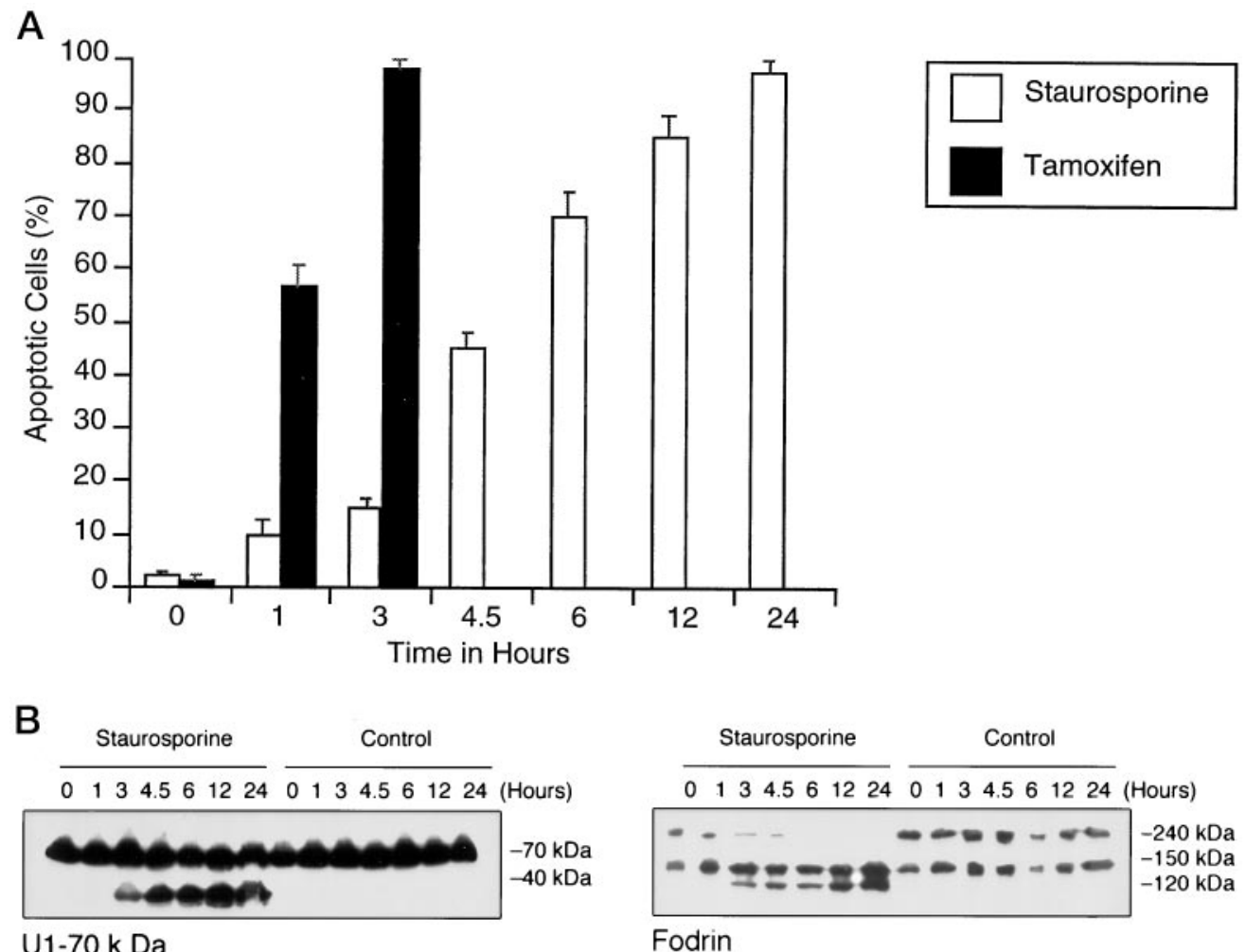

$-70 \mathrm{kDa}$

Fodrin
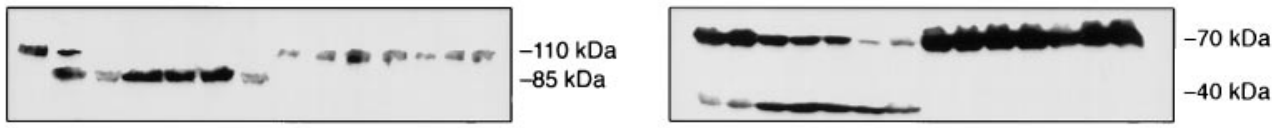

PARP

PKC- $\delta$

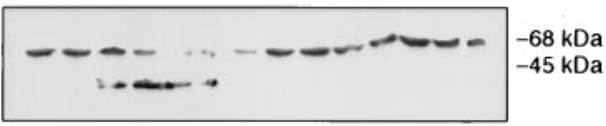

Lamin B

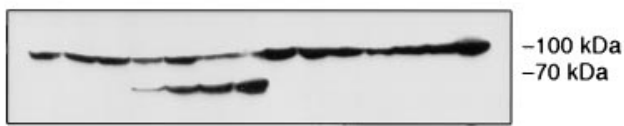

Topo 1

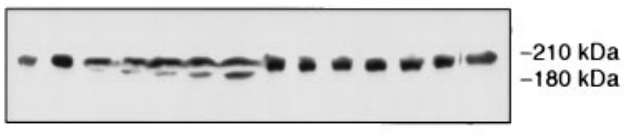

NuMA

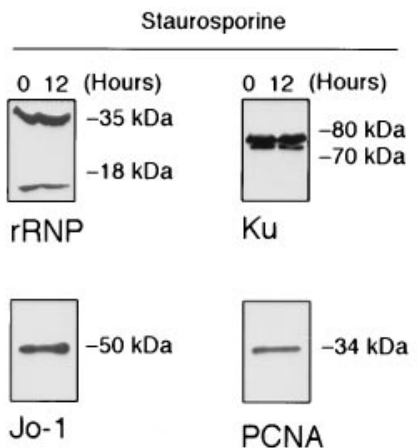

PCNA

Figure 1. Staurosporine and tamoxifen-activated neural apoptosis. $A$, Percentage of apoptotic cells versus time in hours. CSM-25 cells were incubated with staurosporine $\left(10 \mu \mathrm{M}\right.$; white rectangles) or tamoxifen $\left(100 \mu \mathrm{M}\right.$; black rectangles) for the indicated times $\left(34^{\circ} \mathrm{C}\right)$. Apoptotic cells were judged morphologically. Data are mean values $\pm \mathrm{SD}$ as given by error bars (number of independent experiments, $n=3$ ). No significant apoptosis was observed in control cells during the $24 \mathrm{hr}$ period. $B$, Proteolytic profile of protein substrates selectively cleaved during staurosporine-initiated neural apoptosis. CSM-25 cells were incubated with staurosporine for the indicated times $\left(10 \mu \mathrm{M}, 34^{\circ} \mathrm{C}\right)$. Cell lysates were made at the indicated time points and subjected to Western blot analysis. The data in $B$ are representative of at least three independent experiments, depending on substrate.

from cells committed to, but not yet engaged in, apoptosis, thus representing a more upstream stage of apoptosis than extracts taken from apoptotic cells. In this study we made both primed and apoptotic extracts. For our purposes, an extract was considered primed if it met the following criteria: (1) the cells showed little or no morphological change at the time of harvest, and (2) there was little or no cleavage of the cytosolic substrate fodrin.
As shown in Figure $1 A$, we found that the kinase inhibitor staurosporine (Koh et al., 1995) induced a relatively rapid $(>95 \%$ apoptotic cell death within $24 \mathrm{hr}$ for $10 \mu \mathrm{M}$ staurosporine) and relatively synchronous apoptosis in the CSM-25 neural cell line, as judged by morphology. Similar results were obtained with the NSC-19 cell line (data not shown).

To define further the appropriate conditions to prepare 


\begin{tabular}{|c|c|c|}
\hline Substrate & Function & Proteolytic fragments \\
\hline & Nuclear substrates & \\
\hline DNA topoisomerase I (Topo I) & Modification of DNA topology (Liu, 1989) & $100 \rightarrow 70 \mathrm{kDa}$ \\
\hline Lamin B & $\begin{array}{l}\text { Nuclear envelope formation; anchoring chromatin to nuclear matrix } \\
\text { (Lazebnik et al., 1995) }\end{array}$ & $68 \rightarrow 45 \mathrm{kDa}$ \\
\hline NuMA & $\begin{array}{l}\text { Involved in nuclear structure and nuclear re-formation (Compton and } \\
\text { Cleveland, 1994) }\end{array}$ & $210 \rightarrow 160,180 \mathrm{kDa}$ \\
\hline PARP & $\begin{array}{l}\text { DNA repair; interaction with chromatin in the nuclear matrix } \\
\text { (Lazebnik et al., 1994) }\end{array}$ & $110 \rightarrow 85 \mathrm{kDa}$ \\
\hline $\mathrm{U} 1-70 \mathrm{kDa}$ & pre-mRNA splicing (Casciola-Rosen et al., 1994) & $70 \rightarrow 40 \mathrm{kDa}$ \\
\hline PCNA & Proliferation-associated DNA replication (Bravo et al., 1987) & Not cleaved \\
\hline \multirow[t]{2}{*}{$\mathrm{Ku}$} & DNA repair (Ajmani et al., 1995) & Not cleaved \\
\hline & Cytosolic substrates & \\
\hline Jo-1 & his tRNA synthetase (Casiano et al., 1996) & Not cleaved \\
\hline rRNP & Ribosomal proteins $\mathrm{P}_{0}, \mathrm{P}_{1}, \mathrm{P}_{2}$ (Casiano et al., 1996) & Not cleaved \\
\hline \multirow[t]{2}{*}{ Fodrin } & Cytoskeletal protein (Martin et al., 1995b) & $240 \rightarrow 150,120 \mathrm{kDa}$ \\
\hline & Nuclear/cytosolic substrates & \\
\hline $\mathrm{PKC}-\delta$ & $\begin{array}{l}\text { Signal transduction; activated in apoptosis; blocked by Bcl-2 (Emoto } \\
\text { et al., 1995) }\end{array}$ & $78 \rightarrow 40 \mathrm{kDa}$ \\
\hline
\end{tabular}

staurosporine-primed extracts and to define the kinetics of apoptotic cell death in CSM-25, we performed a time course with a substrate profile of caspase cleavage events. Table 1 lists nuclear and cytosolic substrates that we found to be cleaved in staurosporine-treated neural cells and gives a brief description of the function of these proteins and their proteolytic fragments. Figure $1 B$ shows the proteolytic profile of 11 substrates in neural cell lines. The cleavage pattern of the neural substrates reported here is in agreement with that reported recently in non-neural cells by Casiano et al. (1996).

The nuclear substrate PARP was fully cleaved within the first $3 \mathrm{hr}$ of staurosporine-induced neural cell death and was the first substrate fully cleaved in our kinetic profile. This is consistent with other kinetic studies of substrate cleavage events indicating that PARP is cleaved early during apoptosis (Tewari et al., 1995; Casiano et al., 1996). After $3 \mathrm{hr}$ of exposure to staurosporine, small amounts of cleaved PKC- $\delta$, lamin B, U1-70, fodrin, and NuMA appeared. For the cytoplasmic substrate fodrin, cleavage was complete by $6 \mathrm{hr}$, whereas U1-70, NuMA, PKC- $\delta$, Topo I, and lamin B were substantially cleaved $12 \mathrm{hr}$ into staurosporinestimulated apoptosis.

The cleavage events during the neural apoptosis described above were selective, in that some proteins did not undergo proteolysis; for example, the nuclear proteins PCNA and $\mathrm{Ku}$ and the cytoplasmic proteins Jo-1 and rRNP remained uncleaved after $12 \mathrm{hr}$ (Fig. $1 B$ ), consistent with observations in non-neural cells (Casiano et al., 1996).

\section{Activation of neural apoptosis with tamoxifen}

Tamoxifen is effective in the treatment of estrogen receptor (ER)-positive as well as some ER-negative breast cancers (Perry et al., 1995). Although the precise mechanism of action of tamox- ifen, especially in estrogen-independent cells, remains unclear, like staurosporine it is a protein kinase C (PKC) inhibitor (Couldwell et al., 1994), and such inhibition is known to induce apoptosis (Couldwell et al., 1994; Koh et al., 1995). The tamoxifenmediated activation of apoptosis has been reported in the human glioblastoma cell line WITG3 (Iwasaki et al., 1995) and in some non-neural cell lines: rat osteoclasts (Arnett et al., 1996), T-289 melanoma cell line (McClay et al., 1994), and the ER-positive MCF-7 and ER-negative MDA-231 human mammary carcinoma cell lines (Perry et al., 1995; Chen et al., 1996).

Here we report that tamoxifen is an extremely potent inducer of apoptosis in nonglial neural cells. The treatment of nonglial, neural CSM-25 (and NSC) cells with $100 \mu \mathrm{M}$ tamoxifen resulted in the rapid activation of apoptosis $(\sim 100 \%$ in $3 \mathrm{hr}$; Fig. $1 A)$. More importantly, tamoxifen produced a homogeneous detachment of neural cells in $\sim 2 \mathrm{hr}$. Cells were in late apoptosis by 3-6 $\mathrm{hr}$, as judged by morphology. On the other hand, our experience with staurosporine was that, although all of the cells rounded up within $\sim 1 \mathrm{hr}$, the cells detached at various times over several hours and did not exhibit the classic progressive morphological changes in synchrony. For this reason cytoplasmic extracts also were made from tamoxifen-treated cells in addition to extracts made from staurosporine-treated cells. It is worth noting that, at equal concentrations, tamoxifen citrate and 4-hydroxytamoxifen led to a more rapid cell death (data not shown).

\section{Activation of neural cell-free apoptosis with primed extracts}

The results presented above indicate that CSM-25 cells treated with staurosporine or tamoxifen are well into apoptotic cell death by $4-5 \mathrm{hr}$ and $2-3 \mathrm{hr}$ of treatment, respectively. Therefore, we prepared primed neural cell-free extracts made from cells incu- 
bated with staurosporine or tamoxifen for 2-3 hr and $1 \mathrm{hr}$, respectively. These extracts, labeled as $16,000 \times g$ extracts, were made free of large cellular debris, nuclei, and mitochondria. They also were made to leave the nuclei and mitochondria as intact as possible to prevent contamination of the extract by DNA, nuclear, and mitochondrial proteins. Such extracts were tested regularly by DNA electrophoresis and Western blot probing with cytochrome $c$ antibody to detect contamination.

It has been established in non-neural CFSs that nuclei incubated in a primed extract undergo morphological changes that faithfully reproduce those associated with apoptosis (Martin et al., 1995a). To show that the neural cell-free extracts generated from tamoxifen- or staurosporine-treated cells were potent enough to carry out this aspect of apoptosis, we incubated HeLa, CSM, and rat liver nuclei in primed or normal extract. As shown in Figure 2A, CSM-25 nuclei incubated in NSC-19 tamoxifenprimed extract underwent nuclear changes typical of apoptosis. Initially, they appeared decondensed, with the chromatin dispersed throughout the nuclear body, and nucleolar structures were apparent. Within $30 \mathrm{~min}$ of incubation in the extracts, the nuclear chromatin started moving to the nuclear margins, forming crescent-shaped patches along the nuclear envelope, which remained intact. They then further condensed into many discrete convex shapes over the 60-90 min that followed and were totally destroyed in $2 \mathrm{hr}$. These changes in morphology were quantified in Figure $2 B$ by counting apoptotic nuclei versus normal nuclei incubated in both normal and primed extracts. As these data indicate, the vast majority of nuclei incubated for up to $2 \mathrm{hr}$ in normal extract did not undergo morphological change. Similar results were obtained with staurosporine-primed extracts (data not shown).

Apoptosis usually is accompanied by the cleavage of DNA at internucleosomal sites (Wyllie et al., 1980). This effect has been reproduced in several non-neural CFSs (Lazebnik et al., 1993; Newmeyer et al., 1994; Martin et al., 1995a). As Figure 2C illustrates, rat liver nuclei incubated in tamoxifen-primed $16,000 \times g$ CSM-25 extracts also underwent this type of chromatin destruction involving the fragmentation of DNA into integer multiples of $\sim 200$ base pairs, whereas nuclei incubated with normal $16,000 \times g$ neural extracts remained unfragmented.

Another hallmark of apoptosis is the selective proteolytic cleavage of key substrates (Casiano et al., 1996), as discussed and illustrated above. As shown in Figure $2 D$, the incubation of HeLa nuclei in tamoxifen-primed $16,000 \times g$ NSC-34 extract resulted in the cleavage of PARP and PKC- $\delta$, whereas the incubation of normal extract in primed extract resulted in the cleavage of fodrin. No such cleavage events were observed when normal extract was substituted for primed extract. Comparable results were obtained with staurosporine-primed extracts (data not shown). Consistent with reports on non-neural systems (Lazebnik et al., 1994), the cleavage of PARP was blocked by Ac-DEVDCHO (Nicholson et al., 1995), a tetrapeptide inhibitor specific (at $1 \mu \mathrm{M})$ for the CPP32-like [CPP32 is also known as Yama or apopain (Tewari et al., 1995)] caspase family proteases, but not by Ac-YVAD-CHO (Thornberry et al., 1994), a tetrapeptide inhibitor specific (at $1 \mu \mathrm{M}$ ) for the ICE-like caspase family members.

The activation of caspases is known to be essential for apoptotic execution (Schwartz and Milligan, 1996). The kinetics of caspase activation was measured spectrophotometrically by assaying the hydrolysis of a substrate that can be cleaved only by a CPP32-like caspase family member (DEVD-pNA substrate) (Nicholson et al., 1995) or an ICE-like caspase family member
(YVAD-pNA substrate) (Thornberry et al., 1994). As Figure $2 E$ illustrates for a $16,000 \times g$ NSC-19 extract incubated at $37^{\circ} \mathrm{C}$ for $2 \mathrm{hr}$, only the DEVD-pNA substrate is hydrolyzed, implying that CPP32-like caspases are responsible for these selective cleavage events. Note that there is no lag phase seen in Figures $5 C$ and $6 D$, because this extract was incubated for $2 \mathrm{hr}$ before the assay so that it was already active.

\section{Mitochondrial-dependent activation of neuronal cell- free apoptosis with atractyloside and mastoparan}

Atractyloside is an inhibitor of the mitochondrial adenine nucleotide translocator and an inducer of the mitochondrial inner membrane permeability transition (MPT) (Zamzami et al., 1996). The cleavage of fodrin has been shown previously to be tightly coupled to apoptosis (Martin et al., 1995b). As shown in Figure 3 , incubation of a $3000 \times g$ CSM- 25 extract in the presence of atractyloside resulted in the cleavage of fodrin. Beyond this, atractyloside also induced the cleavage of fodrin in a system composed of rat liver mitochondria and a 16,000 $\times g$ CSM-25 extract. However, atractyloside incubated in a $16,000 \times g$ extract alone did not lead to such cleavage, demonstrating that the cleavage of fodrin was mitochondrial-dependent. Furthermore, incubation of the $3000 \times g$ CSM-25 extract alone (or the $16,000 \times$ $g$ CSM-25 extract) did not lead to the cleavage of fodrin.

It has been shown previously that atractyloside induces the MPT and the release of a mitochondrial protein called apoptosisinducing factor (AIF) (Susin et al., 1996). Purified AIF has been shown to induce morphological changes in isolated non-neural nuclei with some similarities to those of apoptosis and to process the caspase family member CPP32 directly into active fragments characteristic of apoptosis (Susin et al., 1996).

The wasp venom peptide toxin mastoparan kills cultured cerebellar granular neurons by apoptosis (Yan et al., 1995). In Figure 4 we show that it also induces cell death in cultured R2 rat cerebellar neuron precursors. This death was determined to be apoptotic within $6 \mathrm{hr}$ at a mastoparan concentration of $50 \mu \mathrm{M}$ and necrotic at a concentration of $100 \mu \mathrm{M}$ or greater, as measured by morphology (data not shown). Like atractyloside, mastoparan induces the MPT (Pfeiffer et al., 1995). Furthermore, mastoparan interacts with the mitochondria outer membrane to release mitochondrial proteins even before the MPT (Nicolay et al., 1994).

In light of the above and with the understanding that atractyloside and mastoparan might act by different mechanisms, it was reasonable to test mastoparan for a similar mitochondrialdependent activation of protease activity unique to apoptosis. Therefore, we incubated a $3000 \times g$ CSM-25 extract with mastoparan. In addition to the cleavage of the cytoskeletal protein fodrin, we found that the caspase family member CPP32 was processed to the active forms found in apoptosis (Fig. $5 A$ ). The longer incubation periods ( $\geq 3 \mathrm{hr}$ ) gave the most complete caspase activation and substrate cleavage (data not shown). Incubation of the $3000 \times g$ CSM-25 extract alone did not lead to the cleavage of fodrin or the processing of CPP32.

Because $3000 \times g$ extracts not only contain mitochondria but also, for example, pieces of plasma membrane and in light of the fact that mastoparan has been shown to interact with G-proteins (Ross and Higashijima, 1994), the next logical step was to determine whether mastoparan indeed had acted through the mitochondria. As shown in Figure $5 A$, we found that mastoparan induced the cleavage of fodrin and processing of CPP32 to active forms in a neural CFS composed of mouse liver mitochondria in a $16,000 \times g$ NT2 extract but did not prime such an extract 
A

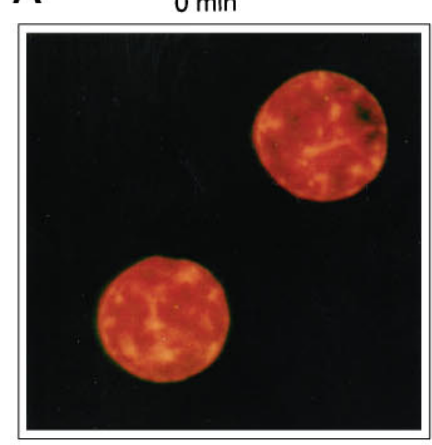

$B_{100}$

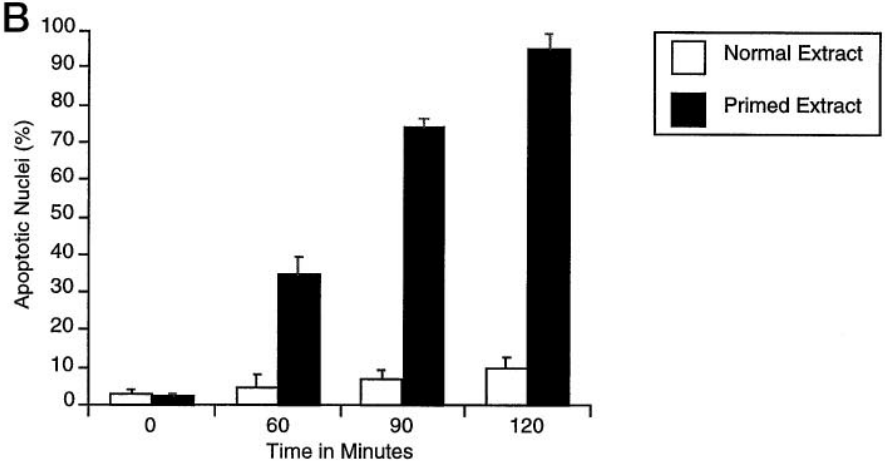

$90 \mathrm{~min}$
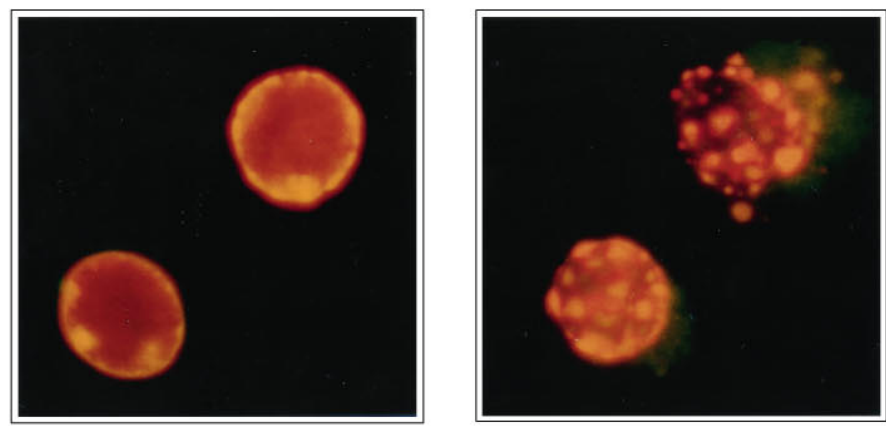

C Nuclei: Normal Extract: Primed Extract:
$120 \mathrm{~min}$
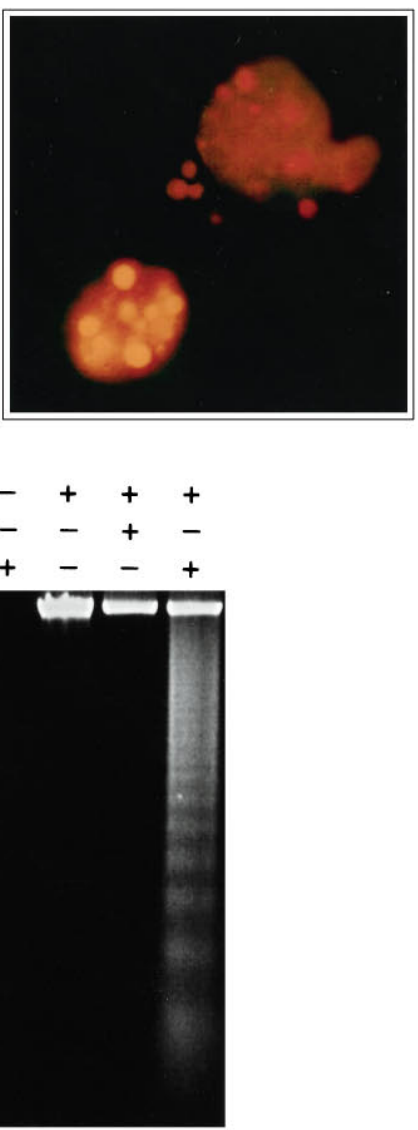

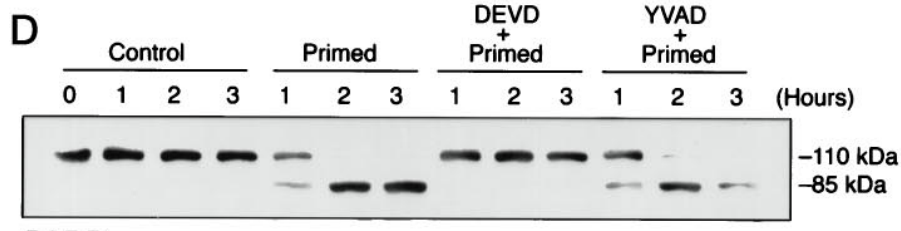

PARP

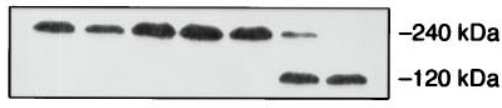

Fodrin

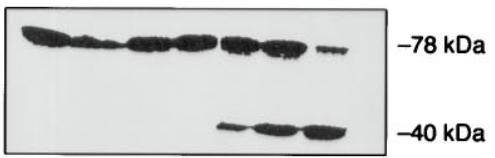

PKC- $\delta$

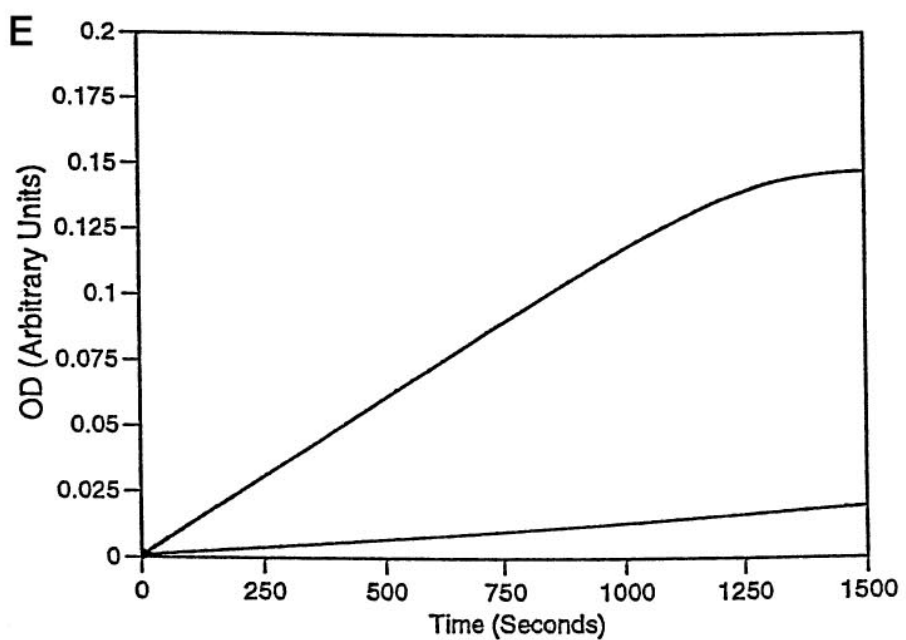

Figure 2. Tamoxifen-primed extract activates neural cell-free apoptosis. $A$, Nuclear morphological changes in CSM nuclei incubated in a $16,000 \times g$ extract made from tamoxifen-primed NSC-19 cells at $34^{\circ} \mathrm{C}$. B. Percentage of apoptotic nuclei incubated as in $A$ in either normal or primed extract. Data are mean values $\pm \mathrm{SD}$ as given by error bars $(n=3)$. No significant apoptotic changes were observed in control nuclei during the $2 \mathrm{hr}$ incubation. $C$, Agarose gel electrophoresis of internucleosomal DNA fragmentation of rat liver nuclei incubated in a $16,000 \times g$ extract made from tamoxifen-primed CSM-25 cells $\left(2 \mathrm{hr}, 34^{\circ} \mathrm{C}\right) . D$, Selective proteolytic cleavage of key substrates from a cell-free reaction of HeLa nuclei incubated for the indicated times in a $16,000 \times g$ extract made from tamoxifen-primed CSM- 25 cells at $37^{\circ} \mathrm{C}$. Cleavage was prevented by Ac-DEVD-CHO, but not by Ac-YVAD-CHO (each at $1 \mu \mathrm{M}$ ). E , The activity of CPP32-like caspases as measured by DEVD-pNA hydrolysis. The CPP32-like caspase activity of a tamoxifen-primed NSC-19 extract after a $2 \mathrm{hr}$ incubation at $37^{\circ} \mathrm{C}$ is given by the top line. The DEVD activity of a normal NSC-19 extract and the YVAD activity of a tamoxifen-primed NSC-19 extract fall at or below the bottom line. In each case the data in $A, C-E$ are representative of at least three independent experiments. 


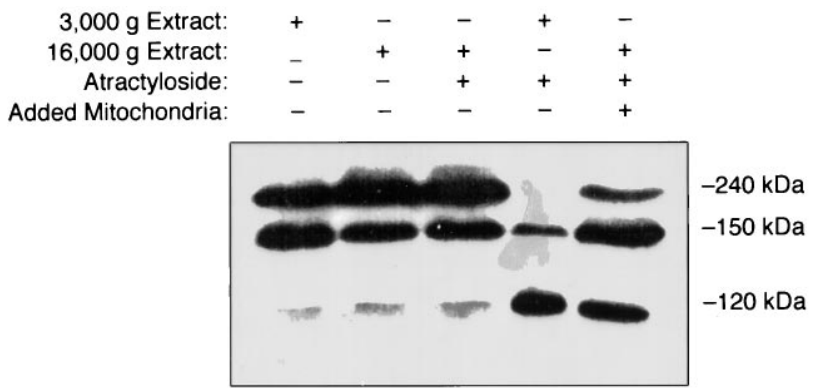

Fodrin

Figure 3. Atractyloside activates neural cell-free apoptosis. Atractyloside $(5 \mathrm{mM})$ was incubated in a $3000 \times g$ extract made from CSM- 25 cells $\left(2-4 \mathrm{hr}, 37^{\circ} \mathrm{C}\right)$. The activation of apoptosis was measured by fodrin cleavage. Atractyloside also induced cell-free apoptosis in a system composed of rat liver mitochondria and $16,000 \times g$ extract from CSM-25 cells. However, atractyloside incubated in a $16,000 \times g$ extract alone did not lead to cell-free apoptosis. The data given in this figure are representative of three independent experiments.

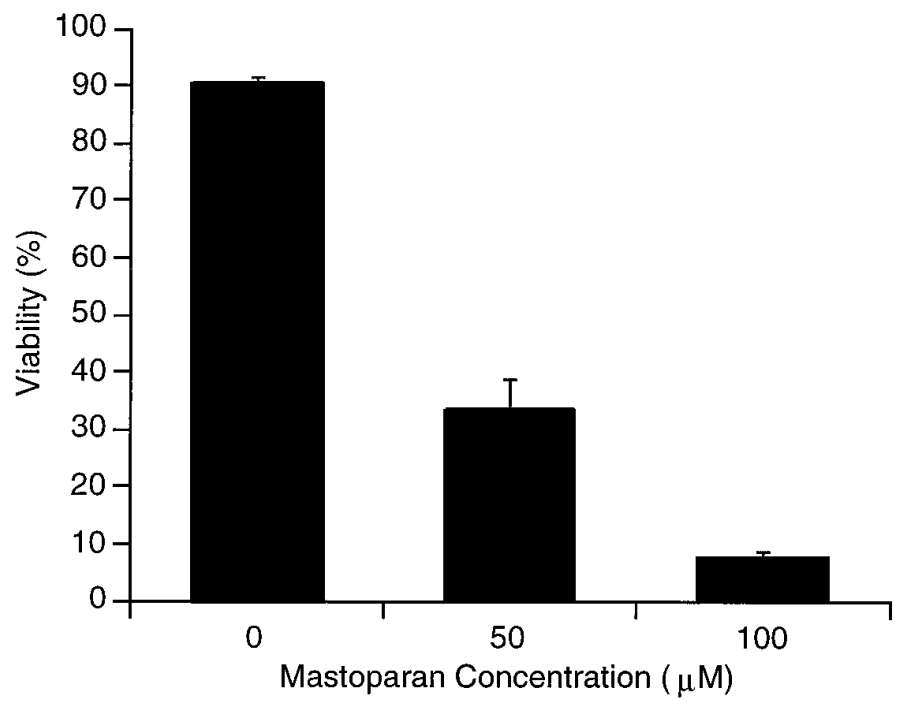

Figure 4. Mastoparan activates neural apoptosis. Mastoparan induces apoptosis in cultured rat cerebellar neuron precursors (the R2 cell line) as measured by cell death, using propidium iodide staining of DNA in cells with a compromised plasma membrane (see Rabizadeh et al., 1993). Data are mean values \pm SD as given by error bars $(n=3)$. No death was observed in control cells $(6 \mathrm{hr})$.

without mitochondria (see Fig. 8). A control nonhelix-forming peptide (DLSLARLAT ARLAI) did not activate these systems (data not shown). Also, the addition of CSM nuclei to these reactions resulted in nuclear morphology characteristic of apoptosis (data not shown). Furthermore, the result was the same for rat neuronal mitochondria in a $16,000 \times g$ extract from primary cerebellar neurons, demonstrating the extension of our neural CFS to primary neurons (Fig. $5 A$ ). When CFS buffer was used instead of extract, there was no detectable fodrin cleavage or CPP32 processing (data not shown), no doubt because there was no detectable fodrin or CPP32 in our mitochondrial preparations (by Western blot). Thus, the cytosol seems to be required for these reactions, although it remains possible that mitochondria have endogenous CPP32 at levels below our detection sensitivity. As we discuss below (see CPP32 Processing in MitochondrialDependent Activation of Cell-Free Apoptosis), tamoxifen did not activate this system.
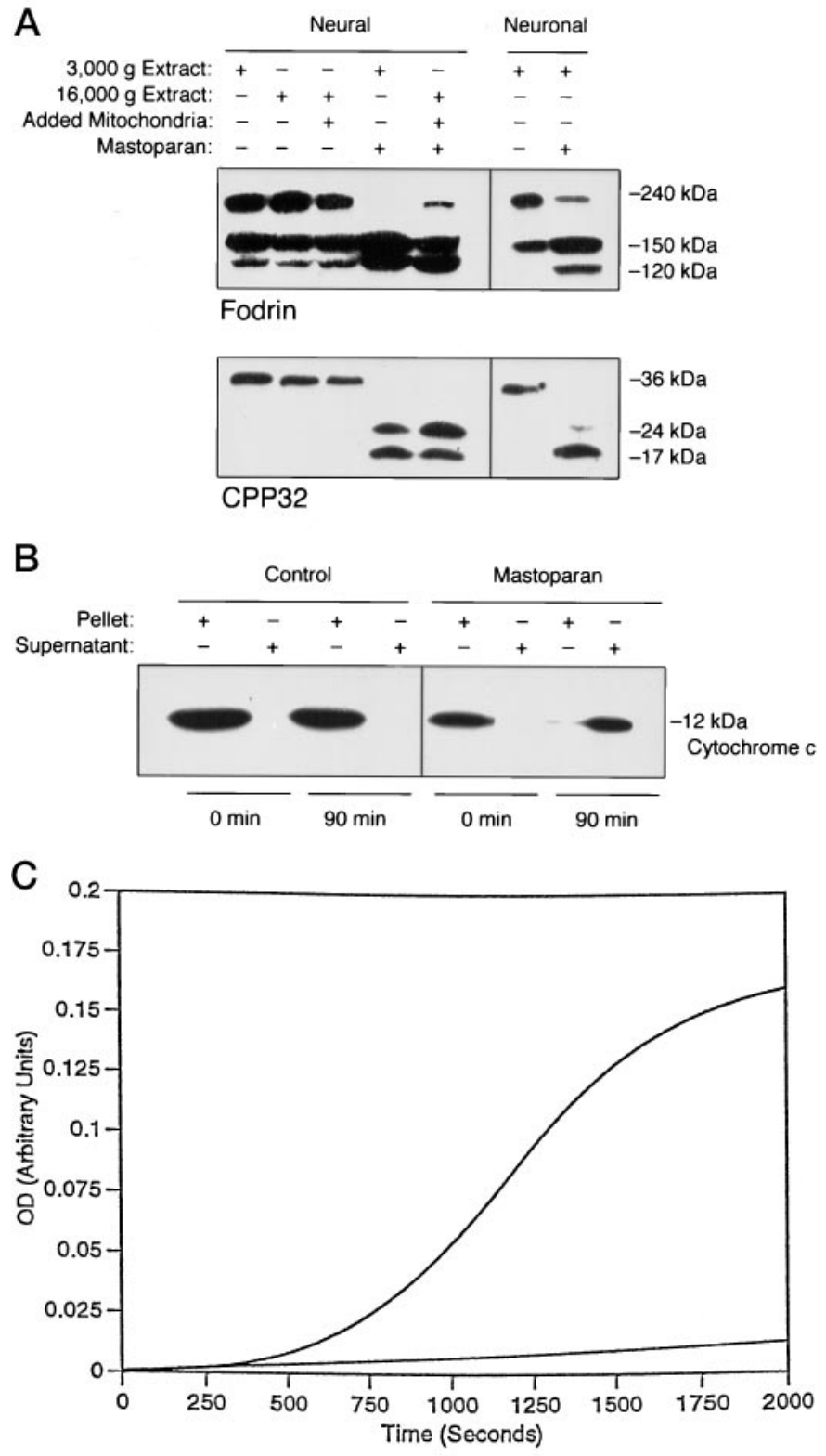

Figure 5. Mastoparan activates neural and neuronal cell-free apoptosis. $A$, Fodrin cleavage and CPP32 processing in a neural cell-free system composed of a $3000 \times g$ extract (containing mitochondria) made from CSM-25 cells in a neural cell-free system of mouse liver mitochondria incubated in a $16,000 \times g$ extract from NT2 cells and in a neuronal cell-free system of rat neuronal mitochondria in a $16,000 \times g$ extract from primary cerebellar neurons $\left(2-4 \mathrm{hr}\right.$ at $\left.37^{\circ} \mathrm{C} ; 50 \mu \mathrm{M}\right)$. Mastoparan did not prime a $16,000 \times g$ extract without mitochondria. $B$, Mastoparan induced release of cytochrome $c$ from mitochondria. Mouse liver mitochondria incubated with mastoparan under the conditions in $A$ led to the release of cytochrome $c$, as measured by Western blot of the supernatant from the mitochondrial pellet. $C$, The processing of DEVD-pNA substrate by a $16,000 \times g$ normal NT2 extract activated by the concentrated supernatant from $B$ is shown in the top curve $\left(37^{\circ} \mathrm{C}\right)$. The activity of a $16,000 \times g$ normal NT2 extract, of a $16,000 \times g$ normal NT2 extract incubated with mastoparan, and mastoparan in buffer was less than or equal to the activity shown by the bottom curve. In each case the data given in $A-C$ are representative of at least three independent experiments.

The above studies indicate that mastoparan induces a mitochondrial-dependent neuronal cell-free apoptosis, as measured by fodrin cleavage, CPP32 processing to active forms, and the CPP32-like caspase hydrolysis of the DEVD-pNA substrate. 


\section{Mastoparan induces the release of cytochrome $c$ from mitochondria}

Recently, Liu et al. (1996) reported on a CFS that differs from the previously reported systems, in that it uses extracts from normally growing cells that have not been induced to undergo apoptosis. Apoptosis is initiated by the addition of dATP and cytochrome $c$, as opposed to apocytochrome $c$, to extracts generated from healthy cells. Because holocytochrome $c$ is found only in the intermembrane space of mitochondria (Brayer and Murphy, 1996), we decided to determine whether or not mastoparan releases cytochrome $c$ from mitochondria. This was done, however, with the knowledge that AIF (Zamzami et al., 1996) or another mediator could have been released from the mitochondria to cause cell-free apoptosis and, moreover, that the actual physiological mechanism by which mastoparan kills might not involve mitochondria. Nevertheless, as illustrated in Figure $5 B$, we found that mastoparan incubated with mouse liver mitochondria led to the release of cytochrome $c$ (as measured by Western blot), whereas control reactions did not release cytochrome $c$. Furthermore, as shown in Figure $5 C$, we found that the supernatant from the mastoparan-treated mitochondria activated a $16,000 \times g$ normal extract made from NT2 cells, as measured by the processing of DEVD-pNA substrate. The supernatant from control reactions did not activate the $16,000 \times g$ extracts.

\section{Postmitochondrial activation of neuronal cell-free apoptosis with cytochrome $c$ and dATP}

As discussed in the previous section, Liu et al. (1996) have reported on a CFS that activates extracts from normally growing cells by the addition of cytochrome $c$ and dATP. This system, when applied to human embryonic kidney 293 cells and human monoblastic U937 cells, reproduces nuclear and DNA fragmentation, PARP cleavage, and the processing of CPP32 to active forms found in apoptotic cell death.

In light of these results, we added horse heart cytochrome $c$ and dATP (cytochrome $c /$ dATP) to $16,000 \times g$ neuronal/neural extracts and found that this system reproduced nuclear and DNA fragmentation (Fig. 6A,B), the proteolysis of fodrin and the processing of CPP32 (Fig. $6 C$ ), and the activation/activity of CPP32-like caspase hydrolysis of DEVD-pNA (Fig. 6D). In addition to rat primary cerebellar granule cell neurons, the system works equally well with neural cell lines such as CSM, NSC, and NT2 and non-neural cell lines such as Jurkat. As we discuss below (see CPP32 Processing in Mitochondrial-Dependent Activation of Cell-Free Apoptosis), we found that tamoxifen and mastoparan did not activate this system.

\section{Some forms of cytochrome $c$ do not activate cell-free apoptosis}

Although the neuronal CFS described in the previous section activates with horse and bovine cytochrome $c$, it does not activate with yeast cytochrome $c$ (ISO-1) nor with partially acetylated horse heart cytochrome $c$ (Fig. 6C). The acetylation process described by Azi et al. (1975) preferentially acetylates surface lysines. In common with this theme of altered lysines, yeast cytochrome $c$ differs from mammalian cytochrome $c$ not only in the number and distribution of lysines (Fig. 7) but also in that lysine 72 is naturally trimethylated in yeast cytochrome $c$ (Clements et al., 1989). Thus, it seems that lysines are important for the function of cytochrome $c$ in activating cell-free apoptosis and that mutations of these lysines might shed further light on the mechanism by which cytochrome $c$ initiates apoptosis.

\section{Cytochrome c/dATP activation of cell-free apoptosis is not inhibited by Bcl-2}

Expression of the proto-oncogene $b c l-2$ inhibits both necrotic and apoptotic cell death in several cell types, including neural cells, and in response to a wide variety of inducers, including serum and growth factor withdrawal (Zhong et al., 1993a), glutamate toxicity (Zhong et al., 1993a), calcium ionophore and membrane peroxidation (Zhong et al., 1993b), protein kinase inhibitors such as staurosporine (Srinivasan et al., 1996), and free-radical inducing agents (Zhong et al., 1993b). With respect to chronic neurodegenerative conditions such as Alzheimer's disease and ALS, it has been shown that the expression of $b c l-2$ inhibits neuronal death induced by both glutamate (Zhong et al., 1993a) and $\beta$-amyloid peptide (Zhong et al., 1993b). Furthermore, with regard to acute neurological events such as stroke, the expression of $b c l-2$ protects neurons during acute in vivo cerebral ischemia (Martinou et al., 1994). The gene $b c l-2$ encodes a $26 \mathrm{kDa}$ membrane-associated protein Bcl-2 that has been located ultrastructurally to the mitochondria, the nuclear membrane, and the endoplasmic reticulum (Hockenbery et al., 1990; de Jong et al., 1994).

Susin et al. (1996) have shown that mitochondria from $b c l-2$ overexpressing cells do not release AIF when incubated with atractyloside. As Figure $6 C$ illustrates, both a $16,000 \times g$ extract made from Bcl-2-overexpressing CSM-25 cells and a $3000 \times g$ extract from such cells (which therefore contains mitochondria) are activated by cytochrome $c$ dATP. These results demonstrate that $\mathrm{Bcl}-2$ can prevent the activation of apoptosis at the mitochondrial level, but not at the postmitochondrial level. This is consistent with the fact that cytochrome $c$ is found only in the mitochondrial intermembrane space (under normal conditions) (Brayer and Murphy, 1996) and that Bcl-2 is found at the contact points between the outer and inner mitochondrial membranes (de Jong et al., 1994).

Therefore, although Bcl-2 can prevent neural cells from undergoing apoptosis induced by such agents as tamoxifen and staurosporine (premitochondrial phase) and can prevent the cell-free activation of apoptosis by such agents as atractyloside (mitochondrial phase), it cannot prevent the cell-free initiation of neural apoptosis by cytochrome $c$ dATP (postmitochondrial phase).

\section{Extract preincubation inhibits cytochrome c/dATP- activated cell-free apoptosis}

A preincubation of $16,000 \times g$ extract renders the extract incapable of activation by cytochrome $c / \mathrm{dATP}$, implying that a temperature-sensitive protease or activator is involved in this apoptotic process (Fig. 6C). Indeed, reactions seemed to run better at 30 than at $37^{\circ} \mathrm{C}$, as measured by the extent of substrate cleavage and pNA hydrolysis (data not shown). Furthermore, the peptide inhibitor Z-Val-Ala-Asp-fluoro-methylketone (zVADfmk) (Casiano et al., 1996) of caspase proteases prevents the activation (Fig. 6C). Finally, cytochrome $c$ alone was usually enough to activate a $16,000 \times g$ extract, without the need for added dATP, although the resulting activity was lower (data not shown).

\section{CPP32 processing in mitochondrial-dependent activation of cell-free apoptosis}

The proteolytic conversion of pro-CPP32 to active forms is a hallmark of apoptosis (Casciola-Rosen et al., 1994; Tewari et al., 1995). Figure 8 shows that tamoxifen induces apoptosis at the premitochondrial level (cells) but does not induce apoptosis at 
A

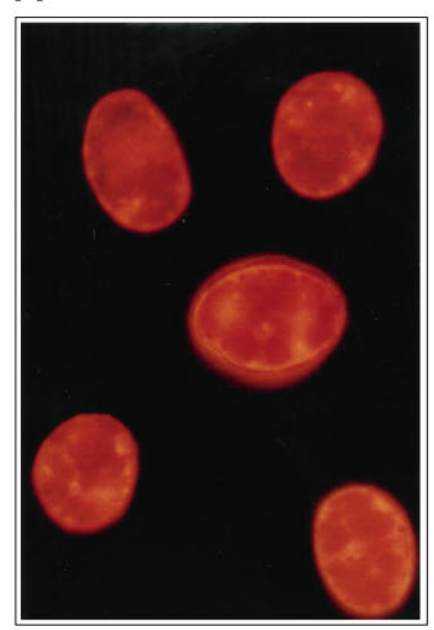

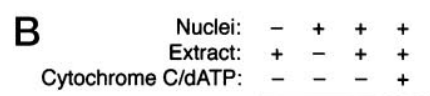

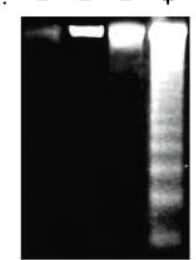

$30 \mathrm{~min}$

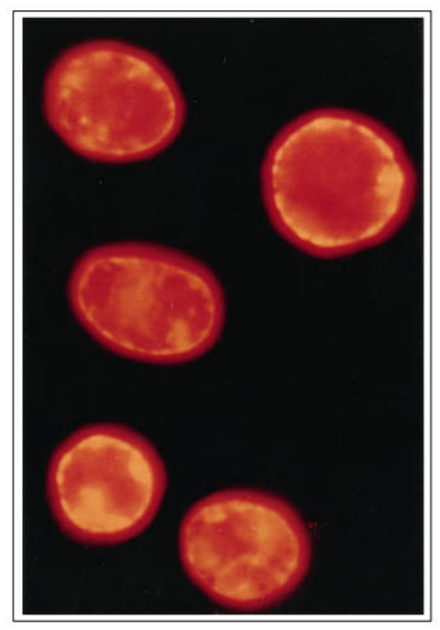

C

C $3,000 \mathrm{~g}$ Extract:
$16,000 \mathrm{~g}$ Extract:
Cytochrome c (Horse):
Cytochrome c (Yeast):
Cytochrome c (Acetylated):
Pre-incubated:
ZVAD:
Added Mitochondria:
$60 \mathrm{~min}$

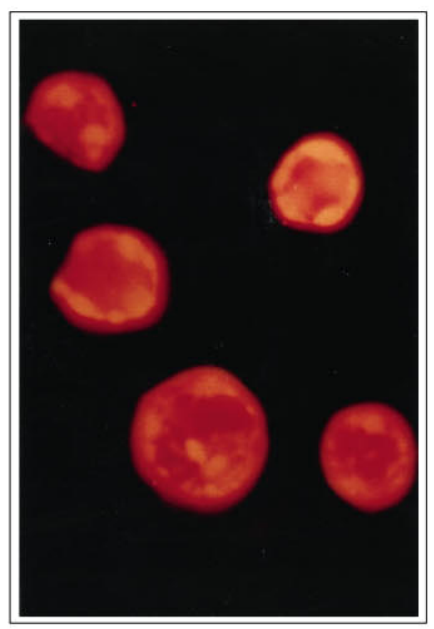

Neuronal

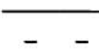

$-\quad-$

$++$

$\begin{array}{ll}+ & + \\ - & +\end{array}$

$-+$

$\begin{array}{ll}- & - \\ - & -\end{array}$

$-\quad-$
$90 \mathrm{~min}$

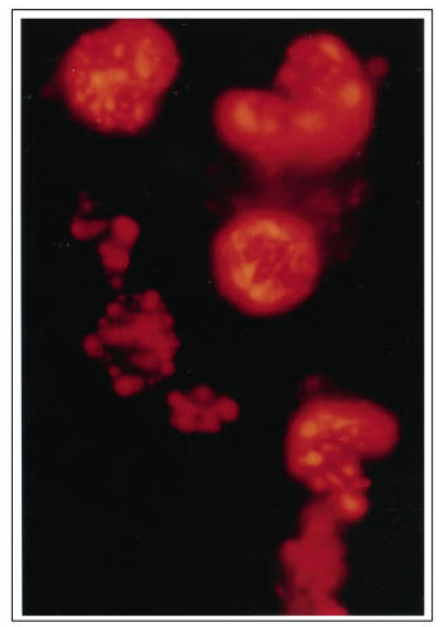

Bcl-2

\begin{tabular}{llll}
\multicolumn{3}{c}{ Bcl-2 } \\
\hline+ & - & + & - \\
- & + & - & + \\
- & - & + & + \\
- & - & - & - \\
- & - & - & - \\
- & - & - & - \\
- & - & - & - \\
- & - & - & +
\end{tabular}

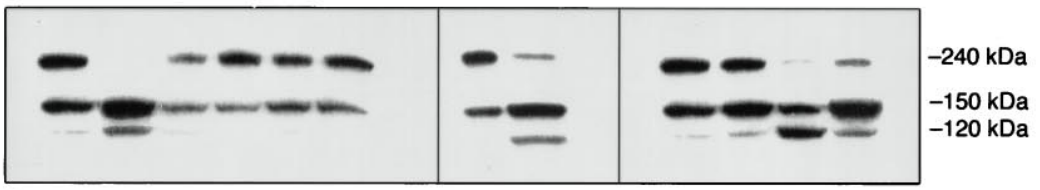

Fodrin

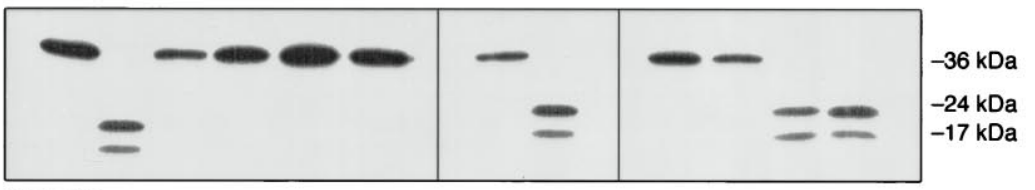

CPP32

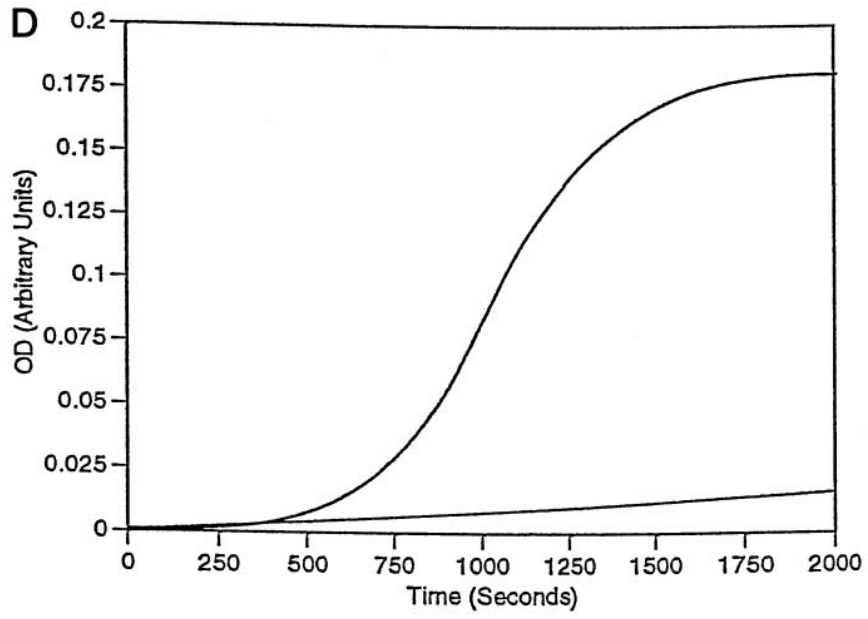

Figure 6. Cytochrome $c$ and dATP activate neural and neuronal cell-free apoptosis. $A$, Nuclear fragmentation of HeLa nuclei incubated in a $16,000 \times$ $g$ NT2 extract with horse heart cytochrome $c$ and dATP. $B$, DNA fragmentation of CSM nuclei incubated in a $16,000 \times g$ CSM extract with horse heart cytochrome $c$ and dATP. $C$, Proteolysis of fodrin and the processing of CPP32 in extracts. Although horse heart cytochrome $c$ activated both $16,000 \times g$ NT2 extracts and $16,000 \times g$ extracts from rat primary cerebellar neurons, yeast and acetylated horse cytochrome $c$ did not activate extracts. A $16,000 \times g$ CSM extract made from Bcl-2-overexpressing cells, with or without mitochondria from Bcl-2-overexpressing cells, and a $3000 \times g$ extract from such cells is activated by cytochrome c/dATP. A 30-60 min preincubation of $16,000 \times g$ extract at $37^{\circ} \mathrm{C}$ renders the extract incapable of activation by cytochrome $c /$ dATP. Furthermore, the peptide inhibitor zVAD-fmk prevents the activation. Incubation conditions for $A-C$ are $10 \mu \mathrm{M}$ cytochrome $c$ and $1 \mathrm{~mm} \mathrm{dATP}$ for $1.5 \mathrm{hr}$ at $37^{\circ} \mathrm{C}$. D. Activation of CPP32like caspase in a $16,000 \times g$ NSC-34 extract incubated with dATP and cytochrome $c$, shown by the top curve, as measured by hydrolysis of DEVDpNA $\left(10 \mu \mathrm{M}\right.$ cytochrome $c$ and $1 \mathrm{mmdATP}$ at $\left.37^{\circ} \mathrm{C}\right)$. The activity of extract alone is shown by the bottom curve.The activities of yeast and partially acetylated cytochrome $c$ in the above system and cytochrome $c /$ dATP in buffer lie at or below the activity of normal extract. In each case the data given in $A-D$ are representative of at least three independent experiments. 


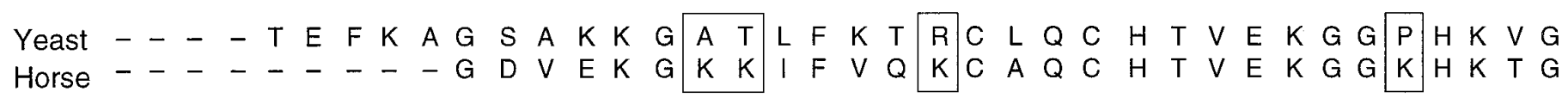

60

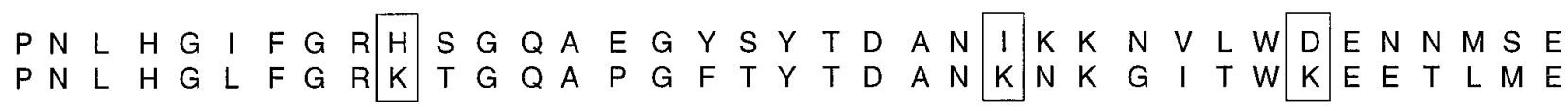

Figure 7. Sequence alignment of horse and yeast (Iso-1) cytochrome $c$. Yeast cytochrome $c$ differs from horse heart cytochrome $c$ in the number and distribution of lysines. The open rectangles highlight lysine residues found in horse, but not in yeast cytochrome $c$. The shaded rectangle highlights lysine 72 , which is naturally trimethylated in yeast cytochrome $c$ (Clements et al., 1989).

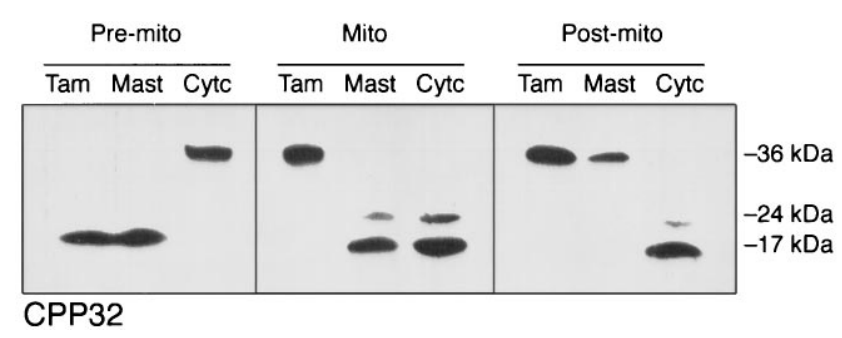

Figure 8. CPP32 processing in apoptosis and cell-free apoptosis. As indicated by the processing of CPP32, Tamoxifen (Tam) induces apoptosis in whole cells (Pre-mito) but does not induce cell-free apoptosis in extract with added mitochondria (Mito) or extract alone (Post-mito). Similar results were obtained for staurosporine (data not shown). Mastoparan (Mast) induces apoptosis at the Pre-mito level and cell-free apoptosis at the Mito level but does not induce cell-free apoptosis at the Post-mito level. Similar results were obtained for atractyloside (data not shown). Cytochrome $c /$ dATP (Cytc) activates cell-free apoptosis at the Mito and Post-mito levels but does not induce apoptosis at the Pre-mito level. For the premitochondrial level, neural cells (CSM, NSC, or NT2) were incubated with tamoxifen $(2 \mathrm{hr})$, mastoparan $(6 \mathrm{hr})$, or cytochrome $c /$ dATP $(8 \mathrm{hr})$. For the mitochondrial level, a cell-free system composed of $16,000 \times g$ neural extract and added rat liver mitochondria was incubated with tamoxifen $(4 \mathrm{hr})$, mastoparan $(4 \mathrm{hr})$, or cytochrome $c /$ dATP $(1 \mathrm{hr})$. For the postmitochondrial level, a cell-free system composed of $16,000 \times g$ neural extract was incubated with tamoxifen $(4 \mathrm{hr})$, mastoparan $(4 \mathrm{hr})$, or cytochrome $c /$ dATP $(1 \mathrm{hr})$. All incubations were run under the following conditions: $100 \mu \mathrm{M}$ tamoxifen; $50 \mu \mathrm{M}$ mastoparan; $10 \mu \mathrm{M}$ cytochrome $c ; 1 \mathrm{mM} \mathrm{dATP} ; 37^{\circ} \mathrm{C}$ ). The data given in this figure are representative of at least three independent experiments.

the mitochondrial level (mitochondria and extract) or the postmitochondrial level (extract). Mastoparan induces apoptosis at the premitochondrial level (cells) and at the mitochondrial level (mitochondria and extract) but does not induce apoptosis at the postmitochondrial level (extract). Finally, cytochrome $c /$ dATP induces apoptosis at the mitochondrial level (mitochondria and extract) and at the postmitochondrial level (extract) but does not induce apoptosis at the premitochondrial level (cells).

\section{DISCUSSION}

We report here the development and use of a CFS for the study of neural apoptosis. This system may be applied to neural cell lines or to primary neurons in culture. Activation of the system results in a reproduction of the events of neuronal apoptosis, including nuclear morphological changes, internucleosomal frag- mentation of DNA, the selective proteolysis of substrates, and the activation of CPP32-like caspases.

During the last few years the substrates of the caspase family of cysteine proteases have received considerable attention because cleavage of these substrates may offer molecular mechanisms for many of the hallmark morphological and functional changes exhibited by apoptotic cells (Casiano et al., 1996). For example, the cleavage of fodrin may lead to morphological alterations such as process retraction, cellular rounding, and bleb formation. The cleavage of nuclear substrates such as the lamins, NuMA, and topoisomerase I may be associated with the dissolution of the nuclear membrane, chromatin condensation, and nuclear fragmentation. Furthermore, the cleavage of substrates during apoptosis can lead to activation, not just inactivation. For example, although PARP cleavage has been reported to lead to inactivation (Lazebnik et al., 1994), the cleavage of PKC- $\delta$ results in the activation of the enzyme (Emoto et al., 1995). As Figure $1 B$ shows, some PKC- $\delta$ is activated ( $40 \mathrm{kDa}$ fragment) at $0 \mathrm{hr}$. This could reflect the presence of apoptotic cells before staurosporine treatment or the basal activity of PKC- $\delta$ in normal cells.

Having established the fundamentals of the neuronal CFS, it was applied in an initial attempt to order the events of neural apoptosis. This approach may be valuable in the determination of the site(s) of action of the mutant proteins associated with neurodegenerative diseases. The findings suggest that a broad classification scheme would include premitochondrial (or extramitochondrial) activation, mitochondrial activation, and postmitochondrial activation.

\section{Premitochondrial level}

Our studies indicate that staurosporine and tamoxifen induce apoptosis in whole cells from which active extracts then may be prepared but do not induce apoptosis directly in cell extracts. This suggests that induction of apoptosis by these agents requires an intact signaling mechanism that is absent in the CFS described here. In light of this, we currently are developing a second generation neuronal CFS that includes additional purified fractions such as plasma membranes (Meier et al., 1984) and lysosomes (Ohshita and Kido, 1995). Because this type of CFS could represent a more upstream system, agents like tamoxifen then might induce apoptosis without the need for intact cells.

\section{Mitochondrial level}

Our studies show that, unlike staurosporine and tamoxifen, atractyloside and mastoparan, both of which induce the mitochondrial 
inner membrane permeability transition (Pfeiffer et al., 1995; Zamzami et al., 1996), activate neural cell extracts directly, without the requirement for whole cells but with the requirement for mitochondria. This lack of need for intact cells argues that the points of apoptosis activation by staurosporine and tamoxifen lie upstream from that of atractyloside and mastoparan. An alternate interpretation is that apoptosis activation by tamoxifen and staurosporine involves a pathway that is independent of that triggered by atractyloside and mastoparan.

Although mastoparan has been shown to have G-protein signaling effects (Ross and Higashijima, 1994) involving the activation of the $G_{o} / G_{i}$ proteins, Yan et al. (1995) found that the pretreatment of granule neurons with pertussis toxin (PTX) did not block mastoparan-induced apoptosis, although it does block $\mathrm{G}_{\mathrm{o}} / \mathrm{G}_{\mathrm{i}}$ activation. So, whereas a PTX-insensitive G-protein still might mediate mastoparan-induced apoptosis, we suggest the alternative view that mastoparan induces mitochondria to release an apoptotic activator such as cytochrome $c$.

Three previous studies, taken together, demonstrate the plausibility of this view. First, mastoparan has been shown to interact with mitochondria in a manner similar to that of mitochondrial presequences. The results of this interaction between mastoparan and the mitochondrial membranes have been ordered by Nicolay et al. (1994), who demonstrated that the interaction of mastoparan with the mitochondrial outer membrane is followed by an increase in the permeability of the mitochondrial outer membrane to adenylate kinase, which is followed in turn by proton leak through the inner membrane, a decrease in the mitochondrial membrane potential, and then the MPT. This is an important result because it demonstrates protein release (adenylate kinase) from the mitochondria before the mitochondria are severely compromised by the MPT. Second, Pfeiffer et al. (1995) demonstrated that mastoparan is a potent inducer of the MPT. Third, atractyloside also induces the MPT and the release of AIF, which is known to induce in vitro apoptotic changes in nuclei, the cleavage of PARP, and the processing of CPP32 (Zamzami et al., 1996).

Therefore, our findings that mastoparan induces the release of a soluble proapoptotic signal (not necessarily limited to cytochrome $c$ ) from mitochondria and a mitochondrial-dependent cell-free apoptosis are not surprising. Nevertheless, it remains unknown whether this mechanism is indeed the mechanism by which mastoparan induces apoptosis in whole cells.

\section{Postmitochondrial level}

Our studies demonstrate that cytochrome $c$ and dATP added together activate neural cell extracts in a manner that is independent of mitochondria. These findings argue that cytochrome $c$ and dATP induce apoptosis at a point distal to those of staurosporine, tamoxifen, atractyloside, and mastoparan. Three points should be highlighted regarding the cytochrome $c /$ dATP activation.

First, not all forms of cytochrome $c$ activate the system. Yeast (ISO-1) and partially acetylated horse cytochrome $c$ are incapable of activating the system. In yeast, lysine 72 is trimethylated (Brayer and Murphy, 1996). Furthermore, the acetylation of lysines (Azi et al., 1975) prevents horse cytochrome $c$ from activating the system. Thus, whether acetylated or methylated, lysine 72 is a good candidate as a residue required for cytochrome $c$ to activate cell-free apoptosis. Work is currently underway to determine which lysines actually are required for cytochrome $c$ to induce cell-free apoptosis.
Second, preincubation of an extract for $30 \mathrm{~min}$ at $37^{\circ} \mathrm{C}$ renders it insensitive to cytochrome $c$ activation, implying that a temperature-sensitive component in the extract is required for cytochrome $c$ /dATP activation. This finding is similar to that of Susin et al. (1996) involving AIF.

Third, Bcl-2 produces an antiapoptotic effect at the premitochondrial and mitochondrial levels but cannot protect against the postmitochondrial activation of apoptosis by cytochrome $c$. Work is underway to determine whether $\mathrm{Bcl}-2$ can protect against mastoparan-initiated cell-free apoptosis.

Use of the cell-free neural apoptosis system described also might lead to new insights into the cytotoxic mechanisms of proapoptotic, mastoparan-like peptides. We recently have found that a peptide consisting of the mastoparan-like region of $\mathrm{p} 75^{\mathrm{NTR}}$ (the low-affinity neurotrophin receptor) is a potent inducer of apoptosis (M. R. Hileman, B. S. Chapman, S. Rabizadeh, V. V. Krishnan, D. E. Bredesen, N. Assa-Munt, L. A. Plesniak, unpublished data; S. Rabizadeh, H. M. Ellerby, L. M. Ellerby, D. E. Bredesen, unpublished data). Furthermore, structural determination of the mastoparan-like $\mathrm{p} 75^{\mathrm{NTR}}$ peptide by nuclear magnetic resonance disclosed a helical structure in the presence of lipid micelles, whereas a nonapoptotic point mutant failed to form a helix (M. R. Hileman, B. S. Chapman, S. Rabizadeh, V. V. Krishnan, D. E. Bredesen, N. Assa-Munt, L. A. Plesniak, unpublished data). Ongoing experiments should determine the organellar requirement for apoptosis activation by the $p 75^{\text {NTR }}$ mastoparan-like peptide. Similarly, the Drosophila proapoptotic protein Reaper (RPR) (Pronk et al., 1996) and mitochondrial presequences (Nicolay et al., 1994) bear some structural similarity (e.g., formation of an $\alpha$-helix) to mastoparan and the mastoparanlike peptide.

Therefore, it is reasonable to hypothesize that there may be a common underlying mechanism of action among some agents of toxic insult, developmental regulation, and neurodegenerative disease involving the activation of apoptosis via the action of mitochondrial "disrupting" peptides. With this in mind, we currently are evaluating p75-like peptides, mitochondrial presequences, and peptides related to RPR in our neuronal CFS to determine whether they induce a mastoparan-like mitochondrialmediated apoptosis.

In summary, this CFS for the study of neuronal apoptosis should find application in a wide range of problems, including the ordering of transduction events in neural apoptosis, determination of the mechanisms by which proapoptotic and antiapoptotic gene products act, identification of the mechanisms by which inhibitors of the process function, and studies of the mechanisms by which mutant proteins induce neurodegenerative disease states.

\section{REFERENCES}

Ajmani AK, Satoh M, Reap E, Cohen PL, Reeves WH (1995) Absence of autoantigen $\mathrm{Ku}$ in mature human neutrophils and human promyelocytic leukemia line (HL-60) cells and lymphocytes undergoing apoptosis. J Exp Med 181:2049-2058.

Alnemri ES, Livingston DJ, Nicholson DW, Salvesen G, Thornberry NA, Wong WW, Yuan J (1996) Human ICE/CED-3 protease nomenclature. Cell 87:171.

Arnett TR, Lindsay R, Kilb JM, Moonga BS, Spowage M, Dempster DW (1996) Selective toxic effects of tamoxifen on osteoclasts: comparison with the effects of estrogen. J Endocrinol 149:503-508.

Azi A, Montecucco C, Richter C (1975) The use of acetylated ferricytochrome $c$ for the detection of superoxide radicals in biological membranes. Biochem Biophys Res Commun 65:597-603.

Bravo R, Frank R, Blundelli PA, McDonald-Bravo H (1987) Cyclin- 
PCNA is the auxiliary protein of DNA polymerase delta. Nature 326:515-517.

Brayer GD, Murphy MP (1996) Structural studies of eukaryotic cytochromes $c$. In: Cytochrome $c$ : a multidisciplinary approach, Chap 3 (Scott RA, Mauk AG, eds), pp 107-200. Mill Valley, CA: University Science Books.

Bredesen DE (1994) Neuronal apoptosis: genetic and biochemical modulation. In: Apoptosis II: the molecular basis of apoptosis in disease (Tomei LD, Cope FO, eds), pp 397-421. Cold Spring Harbor, NY: Cold Spring Harbor Laboratory.

Casciola-Rosen LA, Miller DK, Anhalt GJ, Rosen A (1994) Specific cleavage of the $70 \mathrm{kDa}$ protein component of the U1 small nuclear ribonucleoprotein is a characteristic biochemical feature of apoptotic cell death. J Biol Chem 49:30757-30760.

Cashman NR, Durham HD, Blusztajn JK, Oda K, Tabira T, Shaw IT, Dahrouge S, Antel JP (1992) Neuroblastoma $\times$ spinal cord (NSC) hybrid cell lines resemble developing motor neurons. Dev Dyn 194:209-221.

Casiano CA, Martin SJ, Green DR, Tan EM (1996) Selective cleavage of nuclear autoantigens during CD95 (Fas/APO-1)-mediated T cell apoptosis. J Exp Med 184:765-770.

Chen H, Tritton TR, Kenny N, Absher M, Chiu JF (1996) Tamoxifen induces TGF-beta 1 activity and apoptosis of human MCF-7 breast cancer cells in vitro. J Cell Biochem 61:9-17.

Clements JM, O’Connell LI, Tsunasawa S, Sherman F (1989) Expression and activity of a gene encoding rat cytochrome $c$ in the yeast Saccharomyces cerevisiae. Gene 83:1-14.

Cole R, de Vellis J (1989) Preparation of astrocyte and oligodendrocyte cultures from primary rat glial cultures. In: A dissecting and tissue culture manual of the nervous system (Shahar A, de Vellis J, Vernadakis A, Haber B, eds), pp 121-133. New York: Liss.

Compton DA, Cleveland DW (1994) NuMA, a nuclear protein involved in mitosis and nuclear reformation. Curr Opin Cell Biol 6:343-346.

Cotman CW, Anderson AJ (1995) A potential role for apoptosis in neurodegeneration and Alzheimer's disease. Mol Neurobiol 10:19-45.

Couldwell WT, Hinton DR, He S, Chen TC, Sebat I, Weiss MH, Law RE (1994) Protein kinase $C$ inhibitors induce apoptosis in human malignant glioma cell lines. FEBS Lett 345:43-46.

de Jong D, Prins FA, Mason DY, Reed JC, van Ommen GB, Kluin PM (1994) Subcellular localization of the Bcl-2 protein in malignant and normal lymphoid cells. Cancer Res 54:256-260.

Dragunow M, Faull RL, Lawlor P, Beilharz EJ, Singleton K, Walker EB, Mee E (1995) In situ evidence for DNA fragmentation in Huntington's disease striatum and Alzheimer's disease temporal lobes. NeuroReport 6:1053-1057.

Emoto Y, Manome Y, Meinhardt G, Kisaki H, Kharbanda S, Robertson M, Ghayur T, Wong WW, Kamen R, Weichselbaum R, Kufee D (1995) Proteolytic activation of protein kinase $\mathrm{C} \delta$ by an ICE-like protease in apoptotic cells. EMBO J 24:6148-6156.

Gelbard HA, James HJ, Sharer LR, Perry SW, Saito Y, Kazee AM, Blumberg BM, Epstein LG (1995) Apoptotic neurons in brains from pediatric patients with HIV-1 encephalitis and progressive encephalopathy. Neuropathol Appl Neurobiol 21:208-217.

Hirai Y, Yasuhara T, Yoshida H, Nakajima T, Fujino M, Kitada C (1979) A new mast cell degranulating peptide "mastoparan" in the venom of Vespula lewisii. Chem Pharm Bull (Tokyo) 27:1942-1944.

Hockenbery D, Nunez G, Milliman C, Schreiber R, Korsmeyer S (1990) $\mathrm{Bcl}-2$ is an inner mitochondrial membrane protein that blocks programmed cell death. Nature 348:334-336.

Hovius R, Lambrechts H, Nicolay K, de Kruijff B (1990) Improved methods to isolate and subfractionate rat liver mitochondria. Lipid composition of the inner and outer membrane. Biochim Biophys Acta 1021:217-226.

Iwasaki K, Toms SA, Barnett GH, Estes ML, Gupta MK, Barna BP (1995) Inhibitory effects of tamoxifen and tumor necrosis factor alpha on human glioblastoma cells. Cancer Immunol Immunother 40:228-234.

Koh JY, Wie MB, Gwag BJ, Sensi SL, Canzoniero LM, Demaro J, Csernansky C, Choi DW (1995) Staurosporine-induced neuronal apoptosis. Exp Neurol 135:153-159.

Lazebnik YA, Cole S, Cooke CA, Nelson WG, Earnshaw WC (1993) Nuclear events of apoptosis in vitro in cell-free mitotic events: a model system for analysis of the active phase of apoptosis. J Cell Biol 123:7-22.

Lazebnik YA, Kaufmann SH, Desnoyers S, Poirer GG, Earnshaw WC
(1994) Cleavage of poly (ADP-ribose) polymerase by a proteinase with properties like ICE. Nature 371:346-347.

Lazebnik YA, Takahashi A, Moir RD, Goldman RD, Poirier GG, Kaufmann SH, Earnshaw WC (1995) Studies of the lamin proteinase reveal multiple parallel biochemical pathways during apoptotic execution. Proc Natl Acad Sci USA 92:9042-9046.

Lee TH, Kirschner MW (1996) An inhibitor of p34cdc2/cyclin B that regulates the G2/M transition in Xenopus extracts. Proc Natl Acad Sci USA 93:352-356.

Linnik MD, Zobrist RH, Hatfield MD (1993) Evidence supporting a role for programmed cell death in focal cerebral ischemia in rats. Stroke 24:2002-2009.

Liu LF (1989) DNA topoisomerase poisons as anti-tumor drugs. Annu Rev Biochem 58:351-375.

Liu X, Kim N, Yang J, Jemmerson R, Wang X (1996) Induction of apoptotic program in cell-free extracts: requirement for dATP and cytochrome $c$. Cell 86:147-157.

Lu EJ, Brown WJ, de Vellis J (1980) Ultrastructural differentiation and synaptogenesis in aggregating rotation cultures of rat cerebral cells. J Neurosci Res 5:447-463.

Martin SJ, Newmeyer DD, Mathias S, Farschon DM, Wang H-G, Reed JC, Kolesnick RN, Green DR (1995a) Cell-free reconstitution of Fas-, UV radiation-, and ceramide-induced apoptosis. EMBO J 14:5191-5200.

Martin SJ, O'Brien GA, Nishioka WK, McGahon AJ, Saido T, Green DR (1995b) Proteolysis of fodrin (nonerythroid spectrin) during apoptosis. J Biol Chem 270:6425-6428.

Martinou J, Dubois-Dauphin M, Staple JK, Rodriguez I, Frankowski H, Missotten M, Albertini P, Talabot D, Catsicas S, Pietra C, Huarte J (1994) Overexpression of Bcl-2 in transgenic mice protects neurons from naturally occurring cell death and experimental ischemia. Neuron 13:1017-1030

McClay EF, Albright KD, Jones JA, Christen RD, Howell SB (1994) Tamoxifen delays the development of resistance to cisplatin in human melanoma and ovarian cancer cell lines. Br J Cancer 70:449-452.

McGahon AJ, Martin SJ, Bissonnette RP, Mahboubi A, Shi Y, Mogil RJ, Nishioka WK, Green DR (1995) The end of the (cell) line: methods for the study of apoptosis in vitro. Methods Cell Biol 46:153-185.

Meier PJ, Sztul ES, Reuben A, Boyer JL (1984) Structural and functional polarity of canalicular and basolateral plasma membrane vesicles isolated in high yield from rat liver. J Cell Biol 998:991-1000.

Mochizuki H, Goto K, Mori H, Mizuno Y (1996) Histochemical detection of apoptosis in Parkinson's disease. J Neurol Sci 137:120-123.

Moreadith RW, Fiskum G (1984) Isolation of mitochondria from ascites tumor cells permeabilized with digitonin. Anal Biochem 137:360-367.

Newmeyer DD, Farschon DM, Reed JC (1994) Cell-free apoptosis in Xenopus egg extracts: inhibition by Bcl-2 and requirement for an organelle fraction enriched in mitochondria. Cell 79:353-364.

Nicholson DW, Ali A, Thornberry NA, Vaillancourt JP, Ding CK, Gallant M, Gareau Y, Griffin PR, Labelle M, Lazebnik YA (1995) Identification and inhibition of the ICE/CED-3 protease necessary for mammalian apoptosis. Nature 376:37-43.

Nicolay K, Laterveer FD, Laurens van Heerde W (1994) Effects of amphipathic peptides, including presequences, on the functional integrity of rat liver mitochondrial membranes. J Bioenerg Biomembr 26:327-334.

Ohshita T, Kido H (1995) Simple preparation of rat brain lysosomes and their proteolytic properties. Anal Biochem 230:41-47.

Perry RR, Kang Y, Greaves B (1995) Effects of tamoxifen on growth and apoptosis of estrogen-dependent and -independent human breast cancer cells. Ann Surg Oncol 2:238-245.

Pfeiffer DR, Gudz TI, Novgorodov SA, Erdahl WL (1995) The peptide mastoparan is a potent facilitator of the mitochondrial permeability transition. J Biol Chem 270:4923-4932.

Pleasure SJ, Lee VM-Y (1993) NTera 2 cells: a human cell line which displays characteristics expected of a human committed neuronal progenitor cell. J Neurosci Res 35:585-602.

Pollak M (1996) Enhancement of the antineoplastic effects of tamoxifen by somatostatin analogues. Digestion 57[Suppl 1]:29-33.

Pronk GJ, Ramer K, Amiri P, Williams LT (1996) Requirement of an ICE-like protease for induction of apoptosis and ceramide generation by REAPER. Science 271:808-810.

Rabizadeh S, LaCount DJ, Friesen PD, Bredesen DE (1993) Expression of the baculovirus p35 gene inhibits mammalian neural cell death. J Neurochem 61:2318-2321.

Rabizadeh S, Gralla EB, Borchelt DR, Gwinn R, Valentine JS, Sisodia S, 
Wong P, Lee M, Hahn H, Bredesen DE (1995) Mutations associated with amyotrophic lateral sclerosis convert superoxide dismutase from an antiapoptotic gene to a proapoptotic gene: studies in yeast and neural cells. Proc Natl Acad Sci USA 92:3024-3028.

Reiter LA (1994) Peptidic p-nitroanilide substrates of interleukin-1 beta-converting enzyme. Int J Pept Protein Res 43:87-96.

Rink A, Fung K, Trojanowski JQ, Lee V, Neugebaur E, McIntosh TK (1995) Evidence of apoptotic cell death after experimental traumatic brain injury in the rat. Am J Pathol 147:1-9.

Rosen D, Siddique T, Patterson D, Figlewicz DA, Sapp P, Hentati A, Donaldson D, Goto J, O'Regan JP, Deng HX (1993) Mutations in $\mathrm{Cu} / \mathrm{Zn}$ superoxide dismutase gene are associated with familial amyotrophic lateral sclerosis. Nature 362:59-62.

Ross EM, Higashijima T (1994) Regulation of G-protein activation by mastoparans and other cationic peptides. Methods Enzymol 237:26-37.

Rothman JE (1990) The reconstitution of intracellular protein transport in cell-free systems. Harvey Lect 86:65-85.

Schousboe A, Meier E, Drejer J, Hertz L (1989) Preparation of primary cultures of mouse (rat) cerebellar granule cells. In: A dissecting and tissue culture manual of the nervous system (Shahar A, de Vellis J, Vernadakis A, Haber B, eds), pp 203-206. New York: Liss.

Schwartz LM, Milligan CE (1996) Cold thoughts of death: the role of ICE proteases in neuronal cell death. Trends Neurosci 19:555-562.

Srinivasan A, Foster LM, Testa M-P, Ord T, Kean RW, Bredesen DE, Kayalar C (1996) Bcl-2 expression in neural cells blocks activation of ICE/CED-3 family proteases during apoptosis. J Neurosci 16:5654-5660.

Susin SA, Zamzami N, Castedo M, Hirsch T, Marchetti P, Macho A, Daugas E, Geuskens M, Kroemer G (1996) Bcl-2 inhibits the mitochondrial release of an apoptogenic protease. J Exp Med 184: 1331-1341.
Tewari M, Quan LT, O'Rourke K, Desnoyers S, Zeng Z, Beilder DR, Poirer GG, Salvesen GS, Dixit VM (1995) Yama/CPP32 $\beta$, a mammalian homolog of ced-3, is a CrmA-inhibitable protease that cleaves the death substrate poly (ADP-ribose) polymerase. Cell 81:801-809.

Thornberry NA, Peterson EP, Zhao JJ, Howard AD, Griffin PR, Chapman KT (1994) Inactivation of interleukin-1 beta-converting enzyme by peptide (acyloxy)methyl ketones. Biochemistry 33:3934-3940.

Wyllie AH, Kerr JFR, Currie AR (1980) Cell death: the significance of apoptosis. Int Rev Cytol 68:251-306.

Yamatsuji T, Matsui T, Okamoto T, Komatsuzaki K, Takeda S, Fukumoto H, Iwatsubo T, Suzuki N, Asami-Odaka A, Ireland S (1996a) G-proteinmediated neuronal DNA fragmentation induced by familial Alzheimer's disease-associated mutants of APP. Science 272: 1349-1352.

Yamatsuji T, Okamoto T, Takeda S, Murayama Y, Tanaka N, Nishimoto I (1996b) Expression of V642 APP mutant causes cellular apoptosis as Alzheimer trait-linked phenotype. EMBO J 15:498-509.

Yan GM, Lin SZ, Irwin RP, Paul SM (1995) Activation of G-proteins bidirectionally affects apoptosis of cultured cerebellar granule neurons. J Neurochem 65:2425-2431.

Yoshiyama Y, Yamada T, Asanuma K, Asahi T (1994) Apoptosisrelated antigen, $\mathrm{Le}(\mathrm{Y})$, and nick-end labeling are positive in spinal motor neurons in amyotrophic lateral sclerosis. Acta Neuropathol (Berl) 88:207-211.

Zamzami N, Susin SA, Marchetti P, Hirsch T, Gomez-Monterrey I, Castedo M, Kroemer G (1996) Mitochondrial control of nuclear apoptosis. J Exp Med 183:1533-1544.

Zhong LT, Kane DJ, Bredesen DE (1993a) Bcl-2 blocks glutamate toxicity in neural cell lines. Mol Brain Res 19:353-355.

Zhong LT, Sarafian T, Kane DJ, Charles AC, Mah SP, Edwards RH, Bredesen DE (1993b) Bcl-2 inhibits death of central neural cells induced by multiple agents. Proc Natl Acad Sci USA 90:4533-4537. 